\title{
Impact of ocean acidification on phytoplankton assemblage, growth, and DMS production following Fe-dust additions in the NE Pacific high-nutrient, low-chlorophyll waters
}

\author{
Josiane Mélançon ${ }^{1}$, Maurice Levasseur ${ }^{1}$, Martine Lizotte ${ }^{1}$, Michael Scarratt ${ }^{2}$, Jean-Éric Tremblay ${ }^{1}$, Philippe Tortell ${ }^{3}$, \\ Gui-Peng Yang ${ }^{4}$, Guang-Yu Shi ${ }^{5}$, Huiwang Gao $^{6}$, David Semeniuk ${ }^{3}$, Marie Robert ${ }^{7}$, Michael Arychuk ${ }^{7}$, \\ Keith Johnson $^{7}$, Nes Sutherland ${ }^{7}$, Marty Davelaar ${ }^{7}$, Nina Nemcek ${ }^{7}$, Angelica Peña ${ }^{7}$, and Wendy Richardson ${ }^{7}$ \\ ${ }^{1}$ Université Laval, Department of biology (Québec-Océan), Québec, Québec, Canada \\ ${ }^{2}$ Fisheries and Oceans Canada, Maurice Lamontagne Institute, Mont-Joli, Québec, Canada \\ ${ }^{3}$ University of British Columbia, Department of Earth, Ocean and Atmospheric Sciences, \\ Vancouver, British Columbia, Canada \\ ${ }^{4}$ Ocean University of China, Key Laboratory of Marine Chemistry Theory and Technology, \\ Ministry of Education, Qingdao, China \\ ${ }^{5}$ Chinese Academy of Sciences, Institute of Atmospheric Physics, Beijing, China \\ ${ }^{6}$ Ocean University of China, Key Laboratory of Marine Environment and Ecology, \\ Ministry of Education, Qingdao, China \\ ${ }^{7}$ Fisheries and Oceans Canada, Institute of Ocean Sciences, Sidney, British Columbia, Canada
}

Correspondence to: Josiane Mélançon (josiane.melancon.1@ulaval.ca)

Received: 10 July 2015 - Published in Biogeosciences Discuss.: 6 August 2015

Revised: 13 February 2016 - Accepted: 21 February 2016 - Published: 18 March 2016

\begin{abstract}
Ocean acidification (OA) is likely to have an effect on the fertilizing potential of desert dust in high-nutrient, low-chlorophyll oceanic regions, either by modifying iron (Fe) speciation and bioavailability or by altering phytoplankton Fe requirements and acquisition. To address this issue, short incubations (4 days) of northeast subarctic Pacific waters enriched with either $\mathrm{FeSO}_{4}$ or dust and set at $\mathrm{pH} 8.0$ (in situ) and 7.8 were conducted in August 2010. We assessed the impact of a decrease in $\mathrm{pH}$ on dissolved Fe concentration, phytoplankton biomass, taxonomy and productivity, and the production of dimethylsulfide (DMS) and its algal precursor dimethylsulfoniopropionate (DMSP). Chlorophyll $a$ (chl $a$ ) remained unchanged in the controls and doubled in both the $\mathrm{FeSO}_{4}$-enriched and dust-enriched incubations, confirming the Fe-limited status of the plankton assemblage during the experiment. In the acidified treatments, a significant reduction (by 16-38\%) in the final concentration of chl $a$ was measured compared to their nonacidified counterparts, and a $15 \%$ reduction in particulate organic carbon (POC) concentration was measured in the dust-enriched acidified treat-
\end{abstract}

ment compared to the dust-enriched nonacidified treatment. $\mathrm{FeSO}_{4}$ and dust additions had a fertilizing effect mainly on diatoms and cyanobacteria as estimated from algal pigment signatures. Lowering the $\mathrm{pH}$ affected mostly the haptophytes, but pelagophyte concentrations were also reduced in some acidified treatments. Acidification did not significantly alter DMSP and DMS concentrations. These results show that dust deposition events in a low-pH iron-limited northeast subarctic Pacific are likely to stimulate phytoplankton growth to a lesser extent than in today's ocean during the few days following fertilization and point to a low initial sensitivity of the DMSP and DMS dynamics to OA.

\section{Introduction}

The northeast subarctic Pacific is a high-nutrient, lowchlorophyll (HNLC) region characterized by a phytoplankton assemblage dominated in summer by calcifying coccolithophores and extremely high concentrations of the biogenic 
climate-active gas dimethylsulfide (DMS) (Levasseur et al., 2006; Wong et al., 2006). Several studies have demonstrated that iron $(\mathrm{Fe})$ addition in these Fe-poor waters stimulated phytoplankton growth, in which diatoms often outcompeted other phytoplankton groups, including coccolithophores, and resulted in a decrease in DMS concentrations (Boyd et al., 2005; Hamme et al., 2010; Mélançon et al., 2014). Sources of iron to the northeast subarctic Pacific include vertical mixing, eddies, tidal currents and convection (Cullen et al., 2009; Royer et al., 2010), volcanic ash (Mélançon et al., 2014; O1gun et al., 2011), and desert dust (Boyd et al., 1998; Jickells et al., 2005). Dust, which is considered one of the most important sources, is deposited sporadically, mostly in the spring during occasional dust storms originating from the deserts of northern Asia (Duce and Tindale, 1991). A natural strong dust deposition event has been shown to have nearly doubled particulate organic carbon (POC) concentration in the northeast subarctic Pacific in 2001 (Bishop et al., 2002). The importance of eddies and vertical diffusion in the Gulf of Alaska was recently reviewed and found to be greater than previously thought (Crawford et al., 2007; Johnson et al., 2005; Lam and Bishop, 2008). Ongoing ocean acidification $(\mathrm{OA})$ is however likely to compromise our current understanding of the ecosystem's response to $\mathrm{Fe}$ addition by potentially altering Fe bioavailability (Breitbarth et al., 2010; Shi et al., 2010) and phytoplankton physiology and community composition (Tortell et al., 2002).

$\mathrm{OA}$ is currently in progress, is measurable, and is caused by $\mathrm{CO}_{2}$ emissions to the atmosphere that end up in the ocean (Gattuso et al., 2013). The ocean has taken up one third of the $\mathrm{CO}_{2}$ emissions since the beginning of the industrial era. The dissolution of $\mathrm{CO}_{2}$ in seawater increases the concentration of bicarbonate $\left(\mathrm{HCO}_{3}^{-}\right)$and protons $\left(\mathrm{H}^{+}\right)$(thereby decreasing $\mathrm{pH}$ ) and decreases the concentration of carbonate $\left(\mathrm{CO}_{3}^{2-}\right)$, leading to calcite and aragonite undersaturation. Studies have shown that calcifiers growing in acidified conditions generally present lower net calcification, although their growth, synthesis, and abundance are not generally affected (Kroeker et al., 2013 and references therein). On the other hand, the increase in dissolved $\mathrm{CO}_{2}$ in seawater could favor the growth of phytoplankton groups with low surfacearea-to-volume ratios $(S / V)$ that are limited by the diffusion of $\mathrm{CO}_{2}$ across their surface or with low-efficiency carbonconcentrating mechanisms (CCMs) by reducing the energetic cost of carbon (C) assimilation. Coccolithophores and diatoms generally exhibit low- and high-efficiency CCMs, respectively (Reinfelder, 2011). Alternatively, fertilization with $\mathrm{FeSO}_{4}$ usually favors the growth of diatoms in HNLC waters (Boyd et al., 2007, and references therein). It is not known whether Fe-dust deposition will favor diatoms or coccolithophores in the context of OA. OA could profoundly modify the structure and functioning of a phytoplankton community typically dominated by calcifying haptophytes.

Studies examining the effects of acidification on the bioavailability of $\mathrm{Fe}$ in HNLC regions have provided con- trasting results. Breitbarth et al. (2010) observed a significant increase in $\mathrm{Fe}$ (II) half-life and concentration in response to $\mathrm{CO}_{2}$ enrichment, suggesting that a lower $\mathrm{pH}$ could increase Fe bioavailability. However, Fe bioavailability could also decrease during acidification due to changes in dissolved $\mathrm{Fe}$ speciation. Shi et al. (2010) observed that complexation of $\mathrm{Fe}(\mathrm{III})$ by organic ligands containing acidic, unprotonated functional groups (e.g., carboxylic acid) is strengthened in response to small decreases in surface water $\mathrm{pH}$, resulting in decreased inorganic Fe concentrations - the more bioavailable form of Fe. Furthermore, Fe uptake rates decrease when acquiring organically complexed $\mathrm{Fe}$ - such as $\mathrm{Fe}$ (III) bound to desferrioxamine B (DFB) - because the enzymatic reduction of $\mathrm{Fe}(\mathrm{III})$ at the cell surface may release protons (Shi et al., 2010). Experimental studies with natural communities also yield inconsistent results. A study combining $\mathrm{CO}_{2}$ and Fe manipulations of a natural northwest subarctic Pacific community showed a decrease in coccolithophore abundance at higher $\mathrm{CO}_{2}$ levels (750 and $\left.1000 \mu \mathrm{atm}\right)$ regardless of the $\mathrm{Fe}$ status but no effect of the $\mathrm{CO}_{2}$ level on diatoms nor on total chlorophyll $a$ ( $\operatorname{chl} a$ ) concentrations (Endo et al., 2013). A similar study conducted in HNLC waters of the Weddell Sea, Antarctica, showed an increased C-specific primary productivity with increasing $\mathrm{CO}_{2}$ concentrations in $\mathrm{Fe}$-enriched treatments but not in Fe-depleted treatments (Hoppe et al., 2013).

By altering algal physiology and community composition, OA is likely to influence dimethylsulfoniopropionate (DMSP) and DMS production. DMS originates mostly from the enzymatic cleavage of DMSP, an osmolyte produced by several groups of phytoplankton. DMSP quotas in phytoplankton vary by 3 orders of magnitude, with coccolithophores and diatoms known as strong and poor producers, respectively (Keller et al., 1989). Results from the few studies which have looked at the impact of OA on DMS production are inconsistent. Several of them have reported a decrease in DMS production in acidified waters (Archer et al., 2013; Arnold et al., 2013; Avgoustidi et al., 2012; Hopkins et al., 2010). However, an increase in the concentration of DMS at high $\mathrm{CO}_{2}$ was measured in five bioassays conducted in northwest European waters (Hopkins and Archer, 2014), during the first 10 days of the Third Pelagic Ecosystem $\mathrm{CO}_{2}$ Enrichment Study (PeECE III) (Vogt et al., 2008; Wingenter et al., 2007) and during a mesocosm study conducted in the coastal waters of Korea (Kim et al., 2010). The effect of acidification on DMSP concentration is usually smaller than on DMS, and a greater variability in responses is generally observed: particular or total DMSP increases in some studies (Archer et al., 2013; Arnold et al., 2013), decreases in others (Avgoustidi et al., 2012; Hopkins and Archer, 2014; Hopkins et al., 2010), or shows no response to increased $p \mathrm{CO}_{2}$ (Lee et al., 2009; Vogt et al., 2008). The causes for this variability are not well known.

The objective of this study was to determine how a decrease in $\mathrm{pH}$ by 0.2 units could influence the impact of $\mathrm{Fe}$ 
delivered as $\mathrm{FeSO}_{4}$ or Asian dust on the growth and taxonomic composition of the phytoplankton assemblage of the Fe-limited northeast subarctic Pacific in summer and to explore how these $\mathrm{pH}$-induced changes could affect the production of the climate-active gas DMS.

\section{Material and methods}

\subsection{Experimental setting and location}

On deck incubations were conducted during a cruise along the Line-P transect aboard the Canadian Coast Guard Ship John P. Tully. Water was collected at Ocean Station Papa (OSP) $\left(50^{\circ} \mathrm{N}, 145^{\circ} \mathrm{W}\right)$ from $10 \mathrm{~m}$ depth on 27 August 2010 using a Teflon ${ }^{\circledR}$ diaphragm compressed air activated pump with Teflon ${ }^{\circledR}$ tubing and filtered through a $200 \mu \mathrm{m}$ nylon mesh to remove large zooplankton. A conductivitytemperature-depth (CTD) profile conducted at the same station $2 \mathrm{~h}$ after all bags were filled showed a temperature of $13.5^{\circ} \mathrm{C}$ and a salinity of 32.6 at $10 \mathrm{~m}$ depth. Water was incubated in $5 \mathrm{~L}$ collapsible bags $\left(\right.$ Hyclone ${ }^{\circledR}$ Labtainers $^{\mathrm{TM}}$ ). A flow of surface water was continuously pumped through the incubators to keep the temperature at in situ levels. Measured transmittance shows that the incubation bags filtered $55 \%$ of ultraviolet A (UVA) radiation, $70 \%$ of ultraviolet B (UVB) radiation, and $33 \%$ of photosynthetically active radiation (PAR), irradiance corresponding roughly to a depth of $10 \mathrm{~m}$ for the 400-600 $\mathrm{nm}$ wavelengths (Sasaki et al., 2001). The incubations lasted 4 days and subsampling took place at T0 (0-20 min after acidification and enrichment), T2 (after 2 days), and T4 (at the end of the incubation). All materials in contact with seawater were cleaned to prevent trace-metal contamination according to protocols established by the international GEOTRACES program and available in GEOTRACES' Methods Manual (Cutter et al., 2010).

\subsection{Treatments and acidification protocol}

Incubation bags were submitted to six treatments (in triplicate) representing the following combination of dust or Fe addition and acidification: Control, Control + Acid, Fe, $\mathrm{Fe}+$ Acid, Dust, Dust + Acid (Table 1). The carbonate system parameters and methods used for acidification were based on the recommendations of Riebesell et al. (2010). The technique chosen was the addition of a strong acid $(\mathrm{HCl})$ and bicarbonate $\left(\mathrm{NaHCO}_{3}\right)$. The target value of $750 \mu \mathrm{atm} \mathrm{CO}_{2}$ was chosen to reproduce the concentration of $\mathrm{CO}_{2}$ expected in 2100 following the "business as usual" scenario IS92a by the Intergovernmental Panel on Climate Change (IPCC) (Meehl et al., 2007). Target values of the carbonate system parameters (dissolved inorganic carbon (DIC), $p \mathrm{CO}_{2}$, alkalinity, and $\mathrm{pH}$ ) were calculated using the MS Excel macro CO2SYS (Pierrot et al., 2006) (sets of constants: K1 and K2 from Mehrbach et al., 1973, refitted by Dickson and Millero, 1987; $\mathrm{KHSO}_{4}$ : Dickson, 1990; pH scale: seawater scale
Table 1. Description of Fe or dust additions and acidification status of each treatment. All treatments were conducted in triplicate.

\begin{tabular}{lll}
\hline Treatment & Addition of Fe & Acidification \\
\hline Control & $\mathrm{No}$ & No \\
Control + Acid & $\mathrm{No}$ & Yes \\
$\mathrm{Fe}$ & $\mathrm{FeSO}_{4}\left(+0.6 \mathrm{nmol} \mathrm{L}^{-1}\right)$ & No \\
$\mathrm{Fe}+$ Acid & $\mathrm{FeSO}_{4}\left(+0.6 \mathrm{nmol} \mathrm{L}^{-1}\right)$ & Yes \\
Dust & $\mathrm{CJ} 2$ dust $\left(+2.0 \mathrm{mg} \mathrm{L}^{-1}\right)$ & No \\
Dust + Acid & $\mathrm{CJ} 2$ dust $\left(+2.0 \mathrm{mg} \mathrm{L}^{-1}\right)$ & Yes \\
\hline
\end{tabular}

$\left.\left(\mathrm{mol} \mathrm{kg}{ }^{-1}-\mathrm{SW}\right)\right)$ and are presented in Table 2. To reach these target values, a final concentration of $122.4 \mu \mathrm{mol} \mathrm{\textrm {kg } _ { \mathrm { sw } } ^ { - 1 }}$ of trace-metal-clean $6 \mathrm{~mol} \mathrm{~L}^{-1}$ Seastar $^{\mathrm{TM}}$ Baseline $\mathrm{HCl}$ solution and a final concentration of $115.1 \mu \mathrm{mol} \mathrm{kg}-1$ of a tracemetal-clean solution of $\mathrm{NaHCO}_{3}$ were added to each acidified treatment bag through the Luer lock port using a syringe. The piston was activated several times to ensure proper mixing.

\subsection{Fe and dust addition}

Two sources of Fe were used for the fertilization: $\mathrm{FeSO}_{4}$ and standardized Asian dust CJ-2. Briefly, CJ-2 dust was collected from the Tengger desert surface soil, roughly sieved and blown through a wind tunnel designed to collect fine particles. The median diameter of CJ-2 dust is $24.1 \mu \mathrm{m}$. CJ-2 dust is characterized by an $\mathrm{Fe}$ content of $3.02 \pm 0.12 \%$; Ooki et al. (2009) measured a $0.33 \% \mathrm{Fe}$ solubility, defined as the ratio of dissolved iron to total iron, for CJ-2 dust. For more information on CJ-2 dust, see Nishikawa et al. (2000) and Hwang and Ro (2006). $\mathrm{FeSO}_{4}$ was added at the final concentration of $0.6 \mathrm{nmol} \mathrm{L}^{-1}$, and CJ-2 dust was added at the final concentration of $2 \mathrm{mg} \mathrm{L}^{-1}$. Twenty hours prior to their addition to the bags, dust and $\mathrm{Fe}$ solutions were prepared by adding CJ-2 dust samples or $\mathrm{FeSO}_{4}$ to Milli-Q water. Proper quantities of Fe-enriched solutions were added to each bag with a syringe through the Luer lock port. The piston was pushed and pulled several times to ensure proper mixing. Then, each bag was gently shaken for $5 \mathrm{~min}$ to homogenize its content prior to sampling.

\subsection{Chemical and biological variables}

\subsubsection{Carbonate system}

DIC and alkalinity were measured at T0 and T4. DIC was measured by a coulometric method using a single-operator multi-parameters metabolic analyzer (SOMMA) (Johnson et al., 1993) coupled to a UIC 5011 coulometer, according to standard protocols (Dickson et al., 2007). Samples were calibrated against Andrew Dickson (Scripps) certified reference material (CRM) water batch 101. Alkalinity was measured using an open-cell method consisting of a Brinkmann 
Table 2. Values of DIC, alkalinity, $\mathrm{pH}$, and $p \mathrm{CO}_{2}$ in each treatment at $\mathrm{T} 0$ and $\mathrm{T} 4$.

\begin{tabular}{|c|c|c|c|c|c|c|c|c|c|}
\hline \multirow{3}{*}{$\begin{array}{l} \\
\begin{array}{l}\text { Target values } \\
\text { (acidified) }\end{array} \\
\end{array}$} & & \multicolumn{2}{|c|}{$\begin{array}{c}\text { DIC } \\
\left(\mu \mathrm{mol} \mathrm{kg} \mathrm{sw}_{\mathrm{sw}}^{-1}\right)\end{array}$} & \multicolumn{2}{|c|}{$\left.\begin{array}{c}\text { Alkalinity } \\
(\mu \mathrm{mol} \mathrm{kg}-1 \\
\mathrm{sw}\end{array}\right)$} & \multicolumn{2}{|c|}{$\mathrm{pH}$} & \multicolumn{2}{|c|}{$\begin{array}{l}p \mathrm{CO}_{2} \\
(\mu \mathrm{atm})\end{array}$} \\
\hline & & \multicolumn{2}{|c|}{2107} & \multicolumn{2}{|c|}{2187 (in situ) } & \multicolumn{2}{|c|}{7.78} & \multicolumn{2}{|c|}{750} \\
\hline & & T0 & $\mathrm{T} 4$ & T0 & $\mathrm{T} 4$ & T0 & $\mathrm{T} 4$ & T0 & $\mathrm{T} 4$ \\
\hline \multirow[t]{2}{*}{ Control } & Avg & 1998 & 1998 & 2184 & 2180 & 8.01 & 7.99 & 410 & 439 \\
\hline & SD & 1 & 2 & 8 & 16 & 0.02 & 0.04 & 16 & 41 \\
\hline \multirow[t]{2}{*}{ Control + Acid } & Avg & 2141 & 2147 & 2244 & 2248 & 7.79 & 7.77 & 745 & 799 \\
\hline & SD & 5 & 8 & 3 & 7 & 0.01 & 0.03 & 17 & 67 \\
\hline \multirow[t]{2}{*}{$\mathrm{Fe}$} & Avg & 1992 & 1989 & 2186 & 2187 & 8.03 & 8.02 & 390 & 400 \\
\hline & $\mathrm{SD}$ & 2 & 3 & 2 & 5 & 0.01 & 0.01 & 8 & 14 \\
\hline \multirow[t]{2}{*}{$\mathrm{Fe}+$ Acid } & Avg & 2137 & 2134 & 2240 & 2233 & 7.80 & 7.77 & 743 & 802 \\
\hline & $\mathrm{SD}$ & 5 & 5 & 11 & 10 & 0.02 & 0.02 & 29 & 30 \\
\hline \multirow[t]{2}{*}{ Dust } & Avg & 1991 & 1991 & 2190 & 2187 & 8.04 & 8.02 & 381 & 411 \\
\hline & SD & 2 & 5 & 5 & 3 & 0.02 & 0.02 & 16 & 19 \\
\hline \multirow[t]{2}{*}{ Dust + Acid } & Avg & 2138 & 2135 & 2245 & 2248 & 7.80 & 7.80 & 731 & 734 \\
\hline & SD & 3 & 1 & 9 & 4 & 0.02 & 0.01 & 29 & 21 \\
\hline
\end{tabular}

Dosimat 665 and an Alpha PHE-4841 glass body combination electrode according to standard protocols outlined in the Guide to best practices for ocean $\mathrm{CO}_{2}$ measurements (Dickson et al., 2007). Samples were calibrated against Andrew Dickson (Scripps) CRM water batch 101. Partial pressure of $\mathrm{CO}_{2}\left(p \mathrm{CO}_{2}\right)$ and $\mathrm{pH}$ were calculated using the MS Excel macro CO2SYS as described above.

\subsubsection{Macronutrients and dissolved Fe}

For macronutrients, at each subsampling time, $\sim 10 \mathrm{~mL}$ of each bag was filtered in an in-line syringe filter to remove particles (Polycarbonate $0.8 \mu \mathrm{m}, 25 \mathrm{~mm}$ filters) and placed in polystyrene test tubes. The test tubes were immediately frozen at $-20^{\circ} \mathrm{C}$ in an aluminium freezer block. Concentrations of nitrate, silicic acid, and phosphate were measured ashore using a Technicon AA autoanalyzer II following the methods described in Barwell-Clarke and Whitney (1996).

Dissolved Fe (DFe) samples were collected at each subsampling time by filtering $\sim 125 \mathrm{~mL}(0.22 \mu \mathrm{m})$ into acidcleaned low-density polyethylene bottles under a clean laminar flow hood or in the trace-metal-clean positive-pressure plastic tent (the "bubble") constructed in the main lab as described in Johnson et al. (2005). DFe samples were placed in trace-metal-clean, low-density polyethylene bottles and acidified to $\mathrm{pH} 1.7$ for $20-30 \mathrm{~h}$. Samples were then buffered to $\mathrm{pH} 3.2$ using a formic-acid-ammonium-formate buffer. DFe was quantified according to GEOTRACES protocols available in the Methods Manual (Cutter et al., 2010). All DFe samples were analyzed on board in the bubble using a flow injection analysis (FIA) method where Fe is concentrated from the seawater matrix onto a chelating resin and detected by chemiluminescence as first described by
Obata et al. (1993) with modifications presented in Obata et al. (1997). Samples were pre-concentrated on a resin column of 8-hydroxyquinoline immobilized on silica gel. The eluent was then combined with ammonia, hydrogen peroxide, and luminol. A Hamamatsu photomultiplier tube quantified the light emitted by the reaction of $\mathrm{Fe}$ and luminol as it passed through the detection cell. Fe concentration was determined using an external standard curve. The accuracy of the system was checked by regular measurements of the Sampling and Analysis of Fe (SAFe) standard reference samples D1 and D2 (Johnson et al., 2007). Our average values of the SAFe D1 and two SAFe D2 standards were $0.63 \pm 0.05$ $\mathrm{Fe}(n=7), 0.91 \pm 0.05 \mathrm{Fe}(n=6)$ and $0.90 \pm 0.03 \mathrm{nmol} \mathrm{L}^{-1}$ $(n=4)$, consistent with the community consensus value of $0.67 \pm 04$ (D1), and $0.93 \pm 0.02 \mathrm{nmol} \mathrm{L}^{-1}$ (D2).

\subsubsection{Pigments and particulate organic carbon}

For chl $a$ determination, $305 \mathrm{~mL}$ of water was withdrawn from each bag at each subsampling time. The water was filtered through $25 \mathrm{~mm}$ GF/F filters at $\leq 9.33 \mathrm{kPa}$ vacuum and filters were frozen at $-20^{\circ} \mathrm{C}$ until analysis. Acetone (90\%) was added to extract the pigments $24 \mathrm{~h}$ prior to analysis. Pigments were quantified with a Turner $10 \mathrm{AU}$ fluorometer as described in Strickland and Parsons (1972). To characterize the initial pigment composition by high-performance liquid chromatography (HPLC), two samples of ca. $2 \mathrm{~L}$ were taken directly from the pump when treatment bags were filled at T0. At T4, ca. $1 \mathrm{~L}$ was sampled from two incubation bags. Samples were filtered at $\leq 9.33 \mathrm{kPa}$ vacuum on $47 \mathrm{~mm} \mathrm{GF} / \mathrm{F}$ filters and filters were frozen at $-80^{\circ} \mathrm{C}$ until analysis onshore. Pigments were extracted by placing the filters in $95 \%$ methanol at $-20^{\circ} \mathrm{C}$ in the dark for $24 \mathrm{~h}$ prior to analysis. The 
extracts were filtered through $25 \mathrm{~mm}$ diameter polytetrafluoroethylene (PTFE) syringe filters $(0.2 \mu \mathrm{m}$ pore size) and analyzed using a Waters Alliance 2695 (HPLC) system equipped with a 2996 photodiode array detector (PDA) and a reverse phase C 8 column (Waters Symmetry), with a pyridinecontaining mobile phase (Zapata et al., 2000). Analysis was performed on a $200 \mu \mathrm{L}$ injection of sample mixed with water in the autosampler at a ratio of $5: 1$ immediately prior to injection. Pigment concentrations were quantified using commercially available standards (Danish Hydraulic Institute). The initial pigment ratio matrix loaded into the CHEMTAX program (Table 3) was obtained by averaging the minimum and maximum values of pigment / chl $a$ ratios given in Table 1 of Mackey et al. (1996) and is similar to that used by Suzuki et al. (2002b) and Royer et al. (2010) for samples collected in the subarctic North Pacific. Eight algal groups were quantified using the chemotaxonomy program CHEMTAX (Mackey et al., 1996): cyanobacteria, pelagophytes, haptophytes (including coccolithophores), diatoms, dinoflagellates, prasinophytes, cryptophytes, and chlorophytes. For a description of the pigment types, see Zapata et al. (2004). $\mathrm{POC}$ concentrations were measured at $\mathrm{T} 0$ and at $\mathrm{T} 4$. At $\mathrm{T} 0$, three samples of $500 \mathrm{~mL}$ of seawater were pumped from the sampling station. At $\mathrm{T} 4,500 \mathrm{~mL}$ were sampled from each one of the incubation bags. Samples were filtered on precombusted $25 \mathrm{~mm} \mathrm{GF} / \mathrm{F}$, and the filters were placed in open cryovials and allowed to dry in an oven at $60^{\circ} \mathrm{C}$ for $48 \mathrm{~h}$. The cryovials were then capped and kept in drierite until onshore analysis. POC and particulate nitrogen were measured using a mass spectrometer (Delta Plus, Thermo Finnigan Mat) coupled with an elemental analyzer (CE Instrument model 1110).

\subsubsection{C and Fe uptake rates}

The siderophore DFB has been used as a model ligand for studying the bioavailability of strongly organically complexed Fe in seawater (e.g., Maldonado and Price, 1999; Hutchins et al., 1999; Shi et al., 2010). Iron uptake from DFB occurs through a high-affinity Fe transport system and can reflect the Fe nutritional status of laboratory phytoplankton strains (Maldonado and Price, 1999; Maldonado et al., 2006) and natural phytoplankton assemblages (Semeniuk et al., 2009, 2016; Taylor et al., 2013). Thus, we examined whether uptake rates of Fe complexed to DFB varied among our treatments with varying Fe bioavailability.

Uptake of ${ }^{55} \mathrm{Fe}$ bound to DFB was performed as previously described (Maldonado and Price, 1999; Semeniuk et al., 2009). The $0.5 \mathrm{nM}{ }^{55} \mathrm{Fe}$ (PerkinElmer) was complexed with $5 \%$ excess DFB in pH 3.5 Milli-Q for $30 \mathrm{~min}$ (Maldonado and Price, 1999). The resulting ${ }^{55} \mathrm{FeDFB}$ complex was subsequently equilibrated in $0.22 \mu \mathrm{m}$ filtered seawater for $2 \mathrm{~h}$. Approximately $250 \mathrm{~mL}$ of seawater was subsampled from each incubation bag into acid-cleaned polycarbonate bottles. Just before dawn, the equilibrated ${ }^{55} \mathrm{FeDFB}$ complex and $10 \mu \mathrm{Ci}$ of $\mathrm{H}^{14} \mathrm{CO}_{3}^{-}$(PerkinElmer) were added to each $250 \mathrm{~mL}$ bottle. From each assay bottle, $1 \mathrm{~mL}$ of sample was taken in order to determine the initial total added activities of ${ }^{55} \mathrm{Fe}$ and ${ }^{14} \mathrm{C}$. To prevent inorganic ${ }^{14} \mathrm{C}$ from off-gassing in the initial activity sample vial, $500 \mu \mathrm{L}$ of $5 \mathrm{M} \mathrm{NaOH}$ was added.

After $24 \mathrm{~h}$, the content of each bottle was gently filtered onto a $47 \mathrm{~mm}$ diameter, $1 \mu \mathrm{m}$ porosity polycarbonate filter (AMD) under low vacuum pressure $(\leq 9.33 \mathrm{kPa})$. Just before going dry, the filters were immersed in $5 \mathrm{~mL}$ of Titanium-ethylenediaminetetraacetic acid (Ti-EDTA) wash to remove extracellular Fe (Hudson and Morel, 1989). The filters were then rinsed with $10 \mathrm{~mL}$ of filtered seawater to remove any loosely associated tracer. Filters were placed into $7 \mathrm{~mL}$ borosilicate scintillation vials, immersed in $5 \mathrm{~mL}$ Scintisafe $50 \%$ scintillation cocktail, and conserved in the dark until analysis on a Beckman LS65005514 scintillation counter.

Volumetric Fe uptake and C-fixation rates were calculated as described elsewhere (Maldonado and Price, 1999; Semeniuk et al., 2009). Previous work with phytoplankton assemblages along Line $\mathrm{P}$ has demonstrated that uptake of $\mathrm{Fe}$ from DFB by natural phytoplankton communities is linear over $24 \mathrm{~h}$ (Maldonado and Price, 1999). Thus, Fe uptake rates were calculated assuming that the accumulation of ${ }^{55} \mathrm{Fe}$ by cells was linear during the assay. In order to compare Fe uptake rates among treatments, volumetric rates were normalized to the amount of $\mathrm{C}$ fixed during the assay. The ${ }^{14} \mathrm{C}$ uptake rates normalized to chl $a$ are used here as an indicator of the growth status of the autotrophic assemblage.

\subsubsection{DMS and DMSP concentrations}

DMS and DMSP concentrations were measured following the techniques described in Royer et al. (2010). Briefly, for DMS, water samples were withdrawn from the bags at every subsampling time in $50 \mathrm{~mL}$ serum bottles and analyzed on board using a purge and trap system coupled to a gas chromatograph following methods described in Scarratt et al. (2000). Total DMSP $\left(\right.$ DMSP $\left._{t}\right)$ was measured in an unfiltered water sample of $3.5 \mathrm{~mL}$. The samples were acidified with $50 \mu \mathrm{L}$ of $50 \% \mathrm{H}_{2} \mathrm{SO}_{4}$ and conserved at $4{ }^{\circ} \mathrm{C}$ in the dark until analysis.

\subsection{Statistical analysis}

All statistical analyses were run on Statistical Analysis System (SAS) software. The threshold value for determining statistical significance was $p<0.05$. Repeated-measures analysis of variance (ANOVA) was used to test the difference between treatments and the changes in time for the means of biological and chemical variables. Normality of the data was determined using the Shapiro-Wilk test. ANOVA on ranks was used when normality of the data could not be assumed. Differences between the mean concentrations of phytoplank- 
Table 3. Biomarker pigment initial ratio matrix for CHEMTAX: chl $a$ ratios for eight algal groups.

\begin{tabular}{|c|c|c|c|c|c|c|c|c|c|c|c|c|c|}
\hline Class or pigment & $\mathrm{Chl} c_{3}$ & $\mathrm{Chl} c_{2}$ & Peri & $19^{\prime}$-but & Fucox & Prasinox & Violax & $19^{\prime}$-hex & Diadinox & Allox & Zeax & Chl $b$ & Chl $a$ \\
\hline Prasinophytes & 0 & 0 & 0 & 0 & 0 & 0.360 & 0.114 & 0 & 0 & 0 & 0.142 & 0.888 & 1 \\
\hline Cryptophytes & 0 & 0.126 & 0 & 0 & 0 & 0 & 0 & 0 & 0 & 0.136 & 0 & 0 & 1 \\
\hline Dinoflagellates & 0 & 0.285 & 0.532 & 0 & 0 & 0 & 0 & 0.192 & 0.121 & 0 & 0 & 0 & 1 \\
\hline Haptophytes & 0.238 & 0 & 0 & 0.261 & 0.583 & 0 & 0 & 0.680 & 0.196 & 0 & 0 & 0 & 1 \\
\hline Pelagophytes & 0.125 & 0.127 & 0 & 0.933 & 0.625 & 0 & 0 & 0 & 0.438 & 0 & 0 & 0 & 1 \\
\hline
\end{tabular}

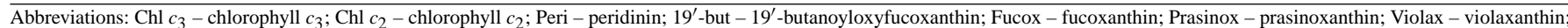
$19^{\prime}$-hex - 19'-hexanoyloxyfucoxanthin; Diadinox - diadinoxanthin; Allox - alloxanthin; Zeax - zeaxanthin; Chl $b$ - chlorophyll $b$; Chl $a-\operatorname{chlorophyll~} a$.

ton groups, as measured by HPLC, were assessed using onefactor ANOVA. Two-way ANOVAs were used to isolate the effect of one factor (acid, Fe addition).

\section{Results}

\subsection{State of the carbonate system, macronutrients, and Fe concentrations}

Table 2 presents the average and standard deviation of the four parameters of the carbonate system measured (DIC and alkalinity) and calculated ( $p \mathrm{CO}_{2}$ and $\left.\mathrm{pH}\right)$ for each treatment at $\mathrm{T} 0$ and $\mathrm{T} 4$. Target values of $\mathrm{pH}$ and $p \mathrm{CO}_{2}$ in the acidified treatments were reached with averages of $7.80 \pm 0.01$ and $740 \pm 23 \mu \mathrm{atm} \mathrm{CO}_{2}$, respectively, at T0. DIC values in acidified treatments reached an average of $2139 \pm 4 \mu \mathrm{mol} \mathrm{kg}_{\mathrm{sw}}^{-1}$, a value $1.5 \%$ higher than the target value but consistent among acidified treatments. Alkalinity values in the acidified treatment were $2243 \pm 7 \mu \mathrm{mol} \mathrm{kg}_{\mathrm{sw}}^{-1}$, a value $2.5 \%$ higher than the in situ (and target) value of $2187 \mu \mathrm{mol} \mathrm{kg}-1$. DIC, alkalinity, and $\mathrm{pH}$ values all remained stable during the 4-day incubations. From $\mathrm{T} 0$ to $\mathrm{T} 4, p \mathrm{CO}_{2}$ values varied by $3-12 \%$ in the acidified treatments and by $2-15 \%$ in the nonacidified treatments, but values of the acidified versus nonacidified treatments remained different from each other.

Initial concentrations of nitrate, silicate, and phosphate were $8.0 \pm 0.2,14.2 \pm 0.2$, and $0.88 \pm 0.02 \mu \mathrm{mol} \mathrm{L}^{-1}$. Nutrient concentrations remained high during the course of the experiments, with nitrate, silicate, and phosphate decreasing by less than 6,4 , and $13 \%$, respectively (data not shown).

$\mathrm{DFe}$, operationally defined as the fraction that passes through a $0.22 \mu \mathrm{m}$ filter, includes soluble and colloidal Fe (de Baar et al., 2005). DFe concentrations started at $0.41 \pm 0.09$ and $0.21 \pm 0.02 \mathrm{nmol} \mathrm{L}^{-1}$ in the Control and Control + Acid treatments, respectively, and decreased to $0.07 \pm 0.01$ and $0.04 \pm 0.01 \mathrm{nmol} \mathrm{L}^{-1}$ over the course of the experiment (Fig. 1a). In the Fe and Fe + Acid treatments, DFe started at $0.65 \pm 0.32$ and $0.47 \pm 0.23 \mathrm{nmol} \mathrm{L}^{-1}$, respectively. The $\mathrm{DFe}$ concentration decreased to ca. $0.11 \mathrm{nmol} \mathrm{L}^{-1}$ on day 2 and to ca. $0.06 \mathrm{nmol} \mathrm{L}^{-1}$ on day 4 in both treatments (Fig. 1b).
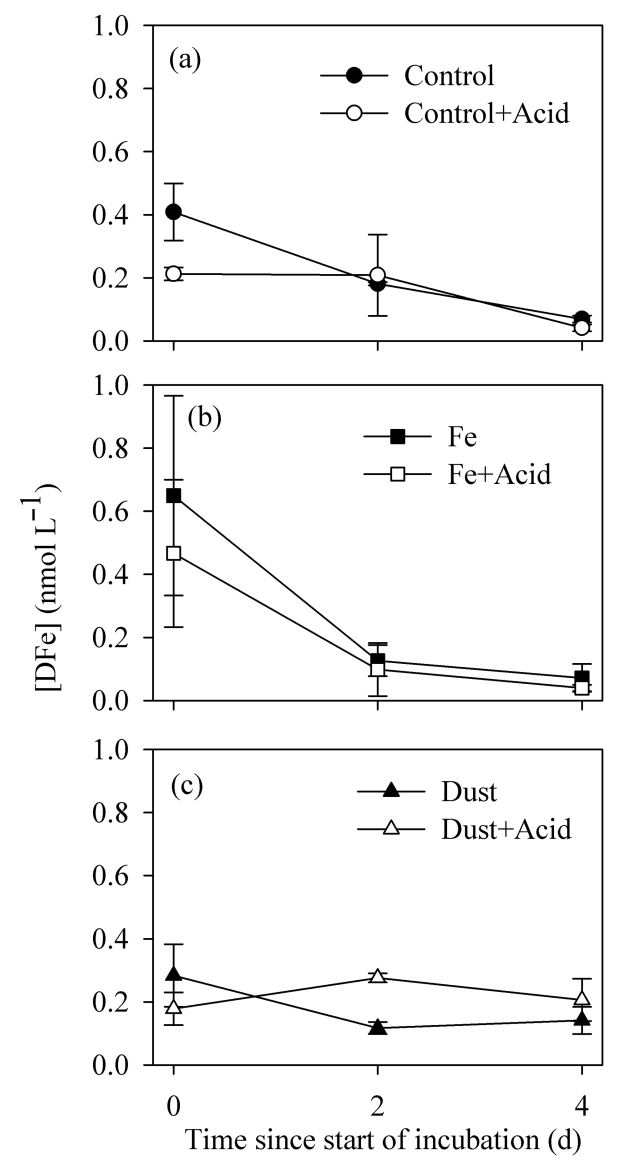

Figure 1. Average concentration of DFe in each treatment during the incubations measured at T0, T2, and T4. Panel (a): Control and Control + Acid. Panel (b): Fe and Fe + Acid. Panel (c): Dust and Dust + Acid. Error bars indicate standard deviations. $n=3$ except for Acid, T0, T2, Dust + Acid, T0, and Control (all times), where $n=2$.

In the Dust treatment, DFe started at $0.28 \pm 0.10 \mathrm{nmol} \mathrm{L}^{-1}$, decreased to $0.12 \pm 0.01 \mathrm{nmol} \mathrm{L}^{-1}$ at $\mathrm{T} 2$, and remained at this level at T4. In the Dust + Acid treatment, DFe started at $0.18 \pm 0.05$, increased to $0.28 \pm 0.01 \mathrm{nmol} \mathrm{L}^{-1}$ at $\mathrm{T} 2$, and decreased slightly to $0.21 \pm 0.07$ at T4 (Fig. 1c). 


\subsection{Plankton biomass}

Average initial chl $a$ concentration in all treatments was $0.39 \pm 0.03 \mu \mathrm{gL}^{-1}$ (Fig. 2). In the Control and Control + Acid treatments, chl $a$ concentration remained stable for the length of the experiment (Fig. 2a). In the Fe treatment, chl $a$ concentrations reached $0.76 \pm 0.16 \mu \mathrm{g} \mathrm{L}^{-1}$ after 4 days, a value significantly higher than measured in the control at the same time ( $p$ value $=0.0269$; Fig. $2 b$ ). In the $\mathrm{Fe}+$ Acid treatment, chl $a$ concentrations increased to $0.58 \pm 0.15 \mu \mathrm{g} \mathrm{L}^{-1}$ after 4 days, a value not significantly different from the one reached at the end of the Fe treatment. The addition of dust also had a significant stimulating effect on phytoplankton growth compared to the Control ( $p$ value: 0.0071 ) with chl $a$ reaching $0.88 \pm 0.23 \mu \mathrm{g} \mathrm{L}^{-1}$ at T4 (Fig. 2c). The chl $a$ concentration reached at T4 in the Dust treatment was not statistically different than the one reached in the Fe treatment. In the Dust + Acid treatment, chl $a$ concentration reached $0.74 \pm 0.01 \mu \mathrm{g} \mathrm{L}^{-1}$ at $\mathrm{T} 4$, a value again not significantly different from the concentrations reached at the end of the Dust treatment (Fig. 2c). Although the difference is not significant, a trend appears in chl $a$ concentrations: chl $a$ concentrations are always slightly lower in the acidified vs. nonacified treatment. In order to detect any interactive effect of $\mathrm{Fe}$ or acidification on chl $a$ and to further explore these apparent trends in chl $a$, all treatments were grouped and tested with a two-factor ANOVA. The first factor, enrichment, had three possible states (Fe, Dust, nil) and the second factor, acid, had two possible states (+ acid, control). This analysis showed a significant effect of the $\mathrm{Fe}$ enrichment ( $p$ value $=0.0060)$ and a significant effect of the acidification ( $p$ value $=0.0385$ ) on chl $a$ concentration. However, no combined effect (synergic or antagonistic) was detected with the two factors.

Initial POC concentration was $75.3 \pm 11.2 \mu \mathrm{g} \mathrm{L}^{-1}$ (not shown) and increased in all treatments including the Control. After 4 days, POC concentrations were similar in the Control $\left(125.5 \pm 0.3 \mu \mathrm{g} \mathrm{L}^{-1}\right)$ and Control + Acid $\left(122.5 \pm 17.6 \mu \mathrm{g} \mathrm{L}^{-1}\right)$ treatments (Fig. 2a). The average POC concentration at $\mathrm{T} 4$ in the $\mathrm{Fe}$ treatment $\left(169.2 \pm 55.8 \mu \mathrm{g} \mathrm{L}^{-1}\right)$ was not statistically different than in the Control. Final POC concentration in the $\mathrm{Fe}+$ Acid treatment $\left(189.3 \pm 29.2 \mu \mathrm{g} \mathrm{L}^{-1}\right)$ was not significantly different than in the Fe treatment but significantly higher than in the Control (Fig. 2b). The highest POC concentration was measured in the Dust treatment $\left(286.7 \pm 39.7 \mu \mathrm{g} \mathrm{L}^{-1}\right)$ and lowering the $\mathrm{pH}$ resulted in a $24 \%$ decrease in POC concentration at T4 (Dust + Acid treatment: $217.4 \pm 2.0 \mu \mathrm{L} \mathrm{L}^{-1}$ ) (Fig. 2c).

\subsection{Taxonomy}

The initial phytoplankton biomass (T0) was dominated by chlorophytes (37\% of total chl $a$ ), followed by haptophytes (31\%), pelagophytes (19\%), and dinoflagellates (13\%) (from Fig. 3). Prasinophyte and cryptophyte biomarkers were
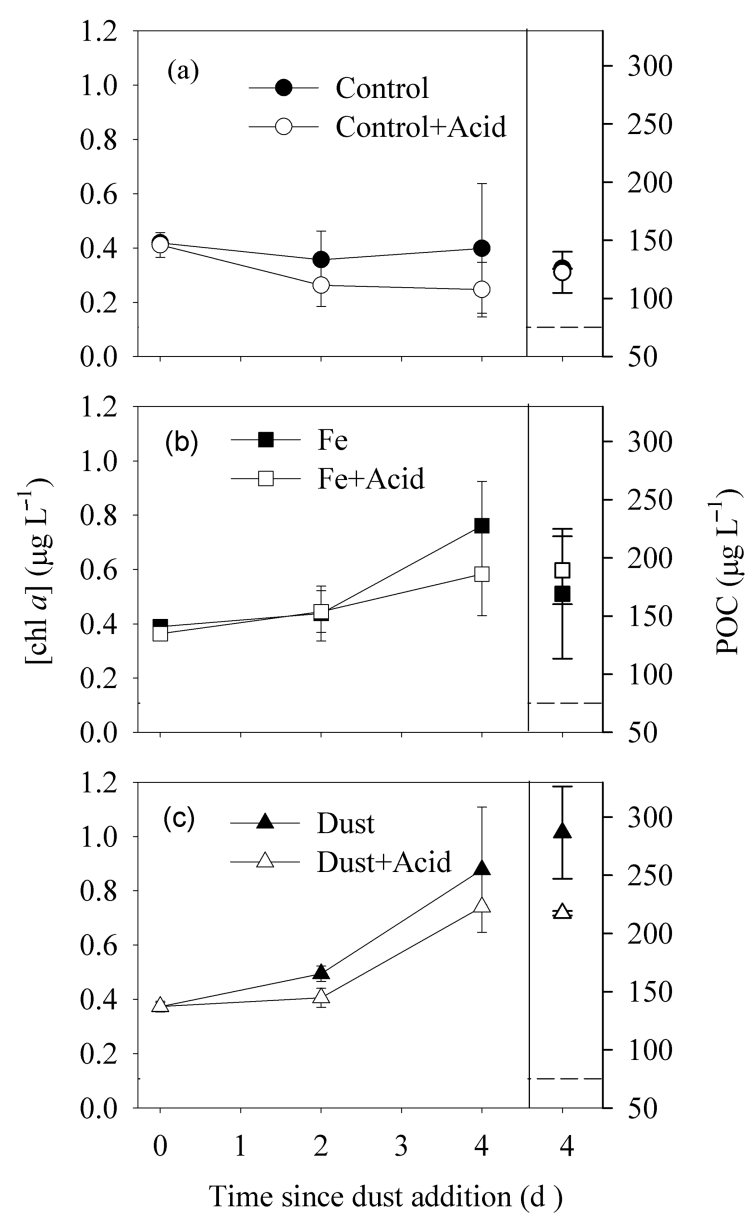

Figure 2. Average concentration of chl $a$ (left axis) during the incubations and POC at T4 (right axis) in each treatment. Panel (a): Control and Control + Acid. Panel (b): $\mathrm{Fe}$ and $\mathrm{Fe}+$ Acid. Panel (c): Dust and Dust + Acid. Error bars indicate standard deviations. Dashed line indicates POC concentration at T0. Chl $a$ : $n=3$ except for Acid, T0, Dust + Acid, T4, Fe + Acid, T0, and Control (all times), where $n=2$ because of missing or unreliable data or contamination (Control 1). POC: $n=3$ except Control, where $n=2$.

not detectable during our experiments. Dinoflagellates were present in low concentrations at $\mathrm{T} 0$ and became undetectable at T4 in the Control and in all treatments (Fig. 3b). In contrast with the dinoflagellates, diatoms and cyanobacteria were below the detection limit at $\mathrm{T} 0$ and became detectable at $\mathrm{T} 4$ in the Control and in all treatments (Fig. 3a, f). These changes in community composition in the control show that the sampling and/or incubation conditions had a negative effect on the growth of dinoflagellates and a positive effect on the growth of diatoms and cyanobacteria. Figure 3 shows that diatoms were responsible for most of the increases in chl $a$ measured in the Fe, Fe + Acid, Dust, and Dust + Acid treatments compared to the Control. The only treatment to show a statistically significant difference with the Control is the Dust treatment, which had significantly higher concentrations of 

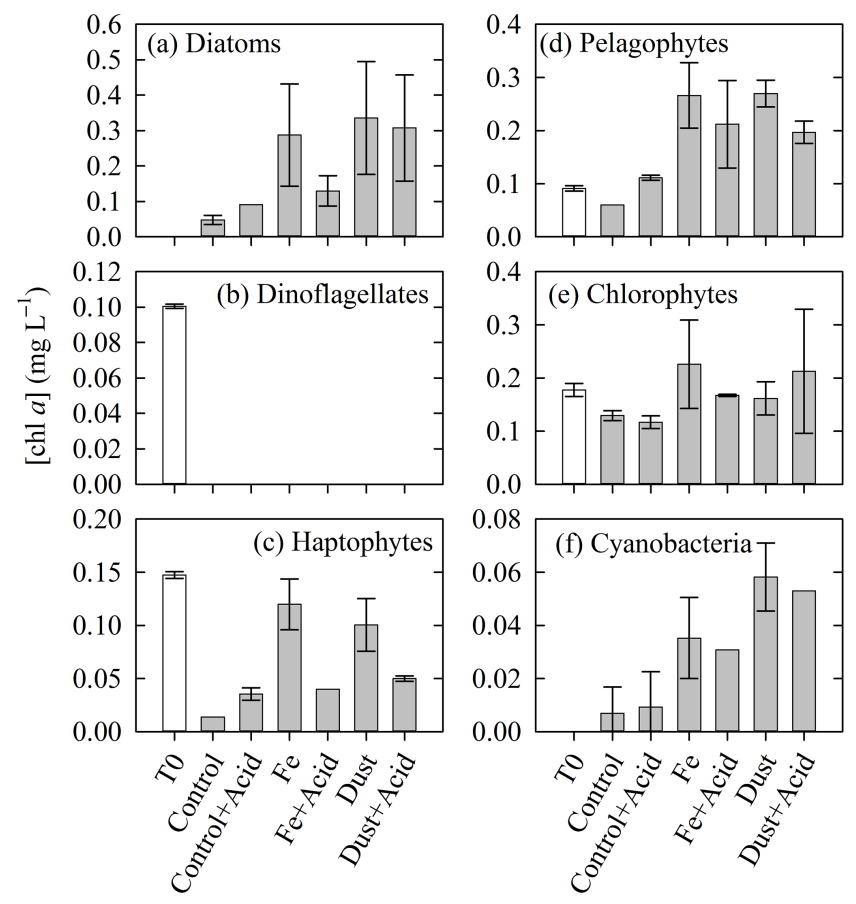

Figure 3. Average chl $a$ concentration $\left(\mu \mathrm{g} \mathrm{L}^{-1}\right)$ attributable to each of the measured groups of phytoplankton initially (T0: white bar) and for each of the treatments after 4 days (T4) of incubation (Control, Control + Acid, Fe, Fe + Acid, Dust, Dust + Acid; gray bars). Panel (a): diatoms; panel (b): dinoflagellates; panel (c): haptophytes; panel (d): pelagophytes; panel (e): chlorophytes; panel (f): cyanobacteria. Error bars indicate standard deviations. $n=2$ except for T0 (all groups but dinoflagellates), where $n=3$, and Acid, diatoms, Control, haptophytes and pélagophytes, Dust + Acid, cyanobacteria and Fe + Acid, haptophytes, and cyanobacteria, where $n=1$.

chl $a$ attributable to diatoms and cyanobacteria than the Control at T4. No statistical difference between any treatment and its acidified counterpart could be detected.

\subsection{Carbon and Fe uptake rates at $\mathrm{T} 4$}

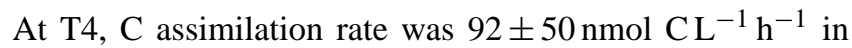
the Control (Fig. 4a). In the Control+ Acid treatment, C

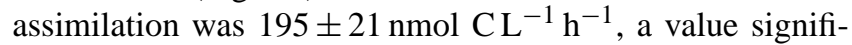
cantly higher than in the Control. $\mathrm{C}$ assimilation rates in the $\mathrm{Fe}$ and $\mathrm{Fe}+$ Acid treatments were significantly higher than in the Control but not different from each other, with values of $189 \pm 23$ and $243 \pm 66 \mathrm{nmol} \mathrm{C} \mathrm{L}^{-1} \mathrm{~h}^{-1}$, respectively. $\mathrm{C}$ assimilation rate in the Dust treatment was similar to the Control with $59 \pm 24 \mathrm{nmol} \mathrm{C} \mathrm{L}^{-1} \mathrm{~h}^{-1}$. Lowering the $\mathrm{pH}$ significantly increased $\mathrm{C}$ assimilation rate in the Dust + Acid treatment $\left(145 \pm 61 \mathrm{nmol} \mathrm{CL}^{-1} \mathrm{~h}^{-1}\right)$ compared to the Dust treatment.

The chl $a$-specific $\mathrm{C}$ assimilation rate (size fraction $>1 \mu \mathrm{m})$ in the Control at T4 was $0.23 \pm 0.01 \mu \mathrm{mol}$ $\mathrm{C} \mu \mathrm{g}$ chl $a^{-1} \mathrm{~h}^{-1}$ (Fig. 4b). Lowering the $\mathrm{pH}$ signifi-
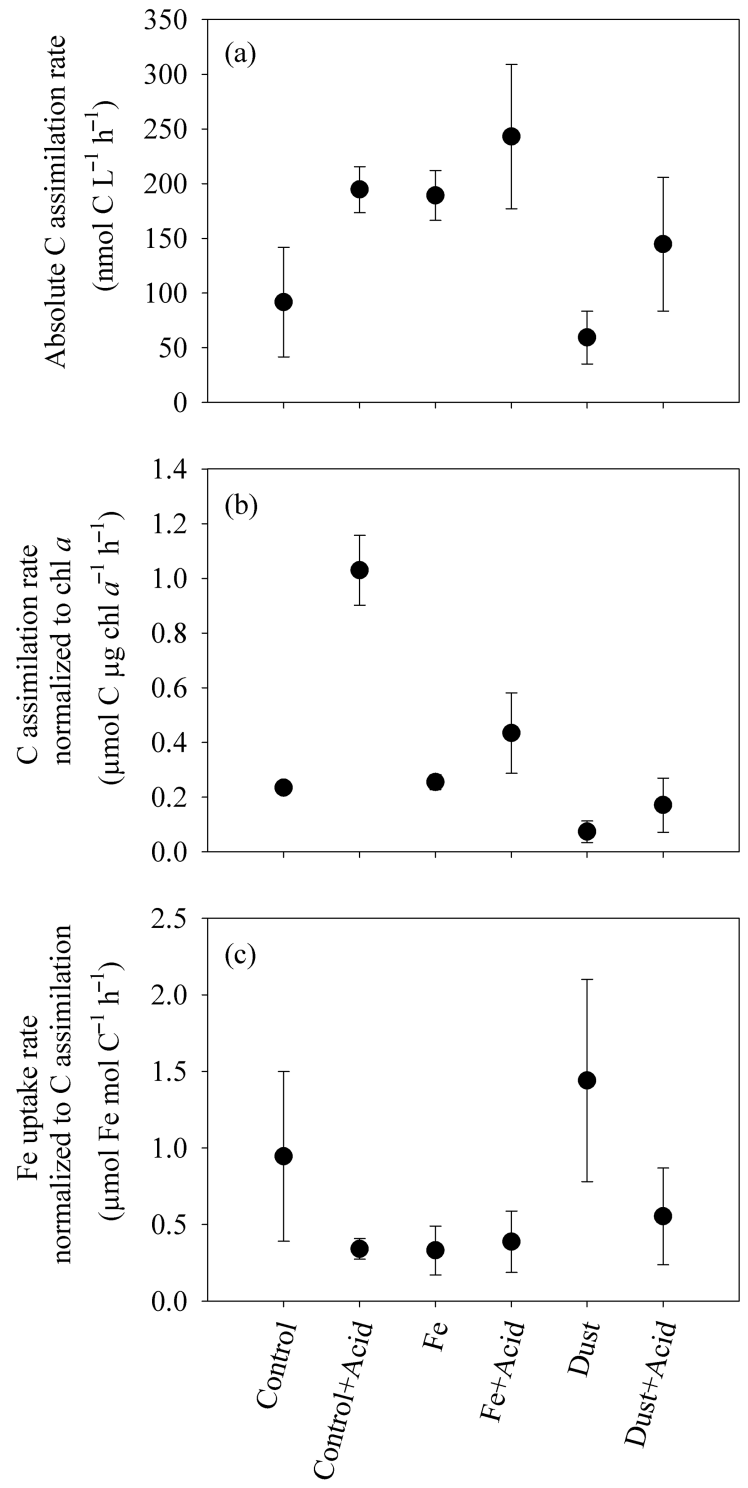

Figure 4. Average (a) absolute $\mathrm{C}$ assimilation rates. $\mathrm{C}$ assimilation rates normalized to chl $a$ concentration at T4 ((b)) and Fe uptake rates normalized to chl $a$ concentration at T4 ((c)). Error bars indicate standard deviations. Absolute $\mathrm{C}$ assimilation rates: $n=3$ except Control and Acid, where $n=2$; C assim norm to chl $a: n=3$ except Control, Acid, and Dust + Acid, where $n=2$; Fe uptake rates normalized to chl $a: n=3$ except Control and Dust + Acid, where $n=2$.

cantly increased the chl $a$-specific $\mathrm{C}$ assimilation rate to $1.03 \pm 0.13 \mu \mathrm{mol} \mathrm{C} \mu \mathrm{g}$ chl $a^{-1} \mathrm{~h}^{-1}$ in the Control + Acid treatment. A similar albeit less pronounced $\mathrm{pH}$-induced increase in chl $a$-specific $\mathrm{C}$ assimilation was observed between the Fe $\left(0.25 \pm 0.03 \mu \mathrm{mol} \mathrm{C} \mu \mathrm{g}\right.$ chl $\left.a^{-1} \mathrm{~h}^{-1}\right)$ and the $\mathrm{Fe}+$ Acid treatments $\left(0.43 \pm 0.15 \mu \mathrm{mol} \mathrm{C} \mu \mathrm{g}\right.$ chl $\left.a^{-1} \mathrm{~h}^{-1}\right)$. The Dust and Dust + Acid treatments had chl $a$-specific C assimilation rates of $0.07 \pm 0.04$ and $0.17 \pm 0.10 \mu \mathrm{mol} \mathrm{C} \mu \mathrm{g}$ $\operatorname{chl} a^{-1} \mathrm{~h}^{-1}$, respectively. It is noteworthy that although com- 

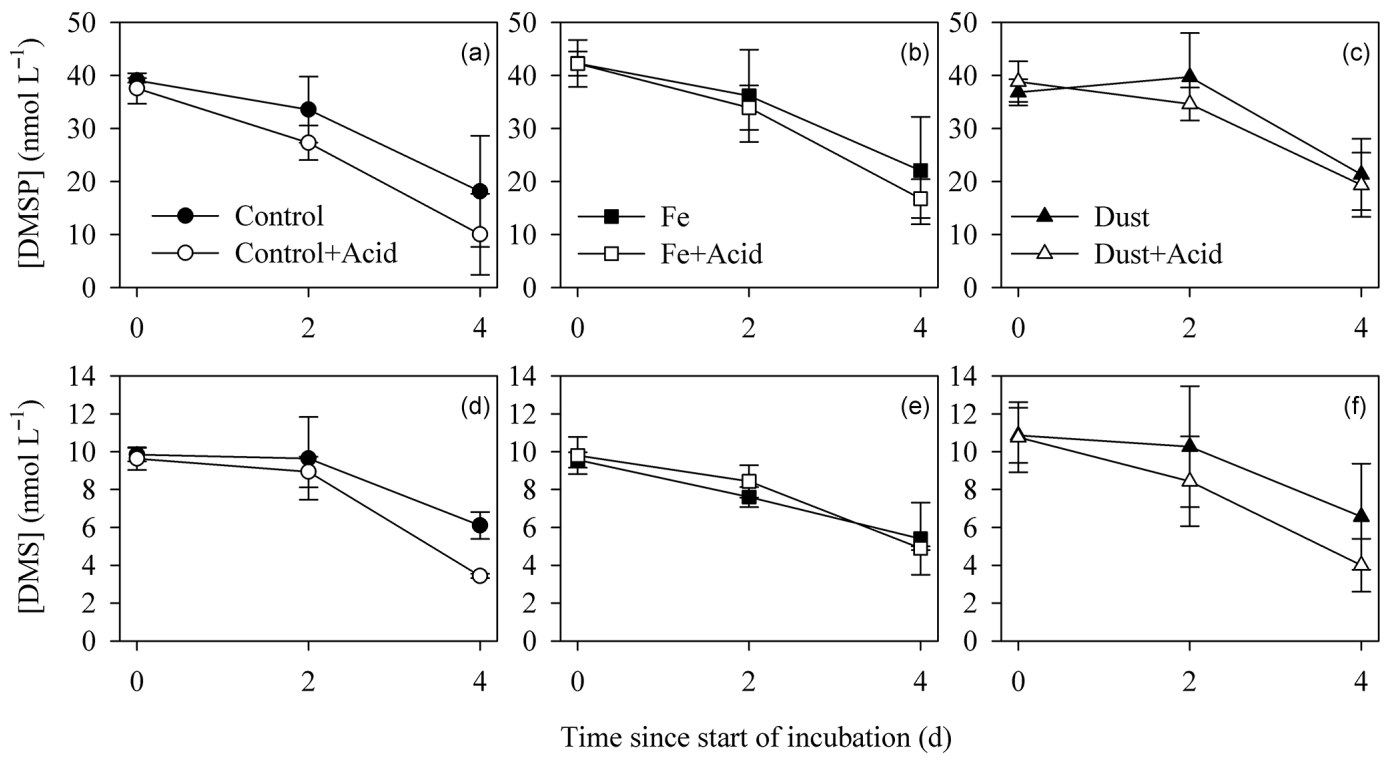

Figure 5. $\operatorname{DMSP}_{\mathrm{t}}(\mathbf{a}, \mathbf{b}, \mathbf{c})$ and DMS $(\mathbf{d}, \mathbf{e}, \mathbf{f})$ concentrations $\left(\mathrm{nmol} \mathrm{L}^{-1}\right)$ in the Control and Control + Acid treatments $(\mathbf{a}, \mathbf{d})$, the Fe and $\mathrm{Fe}+$ Acid treatments $(\mathbf{b}, \mathbf{e})$, and the Dust and Dust + Acid treatments (c, f). Error bars indicate standard deviations. $n=3$ except Control, where $n=2$.

parable biomasses were achieved after 4 days in the $\mathrm{FeSO}_{4}$ or Dust treatments, the chl $a$-specific $\mathrm{C}$ assimilation rate was significantly lower in the Dust treatment as compared to the Fe treatment and in the Dust + Acid compared to the $\mathrm{Fe}+$ Acid treatment.

At T4, FeDFB uptake rates normalized to $\mathrm{C}$ assimilation were $0.94 \pm 0.55 \mu \mathrm{mol} \mathrm{Fe} \mathrm{mol} \mathrm{C}^{-1}$ in the Control, $0.34 \pm 0.07$ in the Control + Acid treatment, $0.33 \pm 0.16$ in the $\mathrm{Fe}$ treatment, and $0.39 \pm 0.20$ in the $\mathrm{Fe}+$ Acid treatment (Fig. 4c). In the dust treatment, FeDFB uptake rate normalized to $\mathrm{C}$ assimilation was high $(1.44 \pm 0.66 \mu \mathrm{mol} \mathrm{Fe}$ mol $\mathrm{C}^{-1} \mathrm{~h}^{-1}$ ), also suggesting a rapid return to Fe-limiting conditions in this treatment. Lowering the $\mathrm{pH}$ decreased the FeDFB uptake rates normalized to $\mathrm{C}$ in the Dust + Acid treatment $\left(0.55 \pm 0.39 \mu \mathrm{mol} \mathrm{Fe} \mathrm{mol} \mathrm{C}{ }^{-1}\right)$ but had no effect

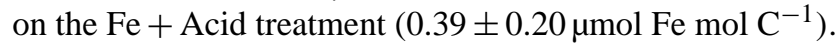

\subsection{DMSP $_{\mathrm{t}}$ and DMS}

Initial average $\mathrm{DMSP}_{\mathrm{t}}$ concentration was $39.8 \pm 3.6 \mathrm{nmol} \mathrm{L}^{-1}$ and decreased between 10 and $21 \mathrm{nmol} \mathrm{L}^{-1}$ at T4 in all treatments (Fig. 5a, b, c). Lowering the $\mathrm{pH}$ resulted in no significant change in $\mathrm{DMSP}_{t}$ concentrations in the control and in the $\mathrm{Fe}$ and Dust treatments. Initial average DMS concentration in all treatments was $10.0 \pm 1.1 \mathrm{nmol} \mathrm{L}^{-1}$ and decreased in all treatments to reach concentrations varying between 3.4 and $6.6 \mathrm{nmol} \mathrm{L}^{-1}$ at T4 (Fig. 5d, e, f). Neither the addition of Fe or dust nor the decrease in $\mathrm{pH}$ had an effect on DMS concentrations.

\section{Discussion}

\subsection{Considerations regarding the experimental protocol}

The experimental approach used in this study has limitations, some of which deserve to be addressed first in order to avoid misinterpretations of the results. First, the sampling and incubation procedures negatively affected the growth of dinoflagellates. For this reason, no conclusion could be drawn on the effect of the treatments on dinoflagellates. For all other taxa, the influence of the treatments could only be addressed by comparing the samples collected at T4. Second, the abrupt acidification rate imposed on the plankton assemblage during our study is not representative of the slow process that is currently taking place in the ocean. Hence, acclimation and adaptation to acidification, which will most probably take place in the natural system, cannot take place during our transient and short experiment. Transient experiments, in the manner conducted here, are nevertheless useful for characterizing the direct impact of OA on Fe bioavailability and to observe short-term resistance or sensitivity of organisms to OA. It is likely that organisms capable of withstanding rapid decreases in $\mathrm{pH}$ will also display tolerance to a more gradual decrease in $\mathrm{pH}$.

\subsection{Initial in situ conditions and impact of acidification}

Oceanic conditions encountered during the experiments were typical of this part of the northeast Pacific and time of year. Macronutrients and chl $a$ concentrations were high and low, respectively, indicative of the HNLC conditions character- 
izing the Gulf of Alaska in summer (Harrison et al., 1999; Hopkinson et al., 2010). DMS concentrations were high but usual for this region in the summer (Wong et al., 2005). The DFe concentration of $0.4 \mathrm{nmol} \mathrm{L}^{-1}$ measured in the Control at T0 was higher than expected, but the Fe-limited status of the plankton community was confirmed by the absence of chl $a$ accumulation in the Control and the increase in chl $a$ induced by the addition of $\mathrm{FeSO}_{4}$ (Fig. 2a, b). Also as expected for this time of the year, the greatest contributors to total chl $a$ included chlorophytes, haptophytes, and pelagophytes (Fig. 3), while diatoms represented minor contributors. Hence, the combined influences of dust and $\mathrm{pH}$ on phytoplankton growth, taxonomy, and DMS production reported in this study can be extrapolated to the northeast subarctic Pacific summer conditions. However, for the reason mentioned above, our protocol does not allow us to draw conclusions on how dinoflagellates, which represented ca. $13 \%$ of the autotrophic biomass in situ, respond to OA.

The abrupt decrease in $\mathrm{pH}$ (by 0.2 units) and increase in $p \mathrm{CO}_{2}$ (by $335 \mu \mathrm{atm}$ ) had no detectable effect on the Fe-limited phytoplankton biomass and community structure (Figs. 2a and 3c). During a comparable experiment conducted in the same region and under similar oceanographic conditions (HNLC waters, phytoplankton dominated by haptophytes and chlorophytes), Hopkinson et al. (2010) showed that increasing $\mathrm{CO}_{2}$ to $760-1204 \mu \mathrm{atm}$ had little effect on chl $a$, nutrient drawdown, or phytoplankton growth rates after 5 days in Fe-limited conditions. In their experiment, they did not observe a decrease in the biomass of haptophytes as during our study, but the absence of a present-day $\mathrm{CO}_{2}$ control (observations restricted to low- and high- $\mathrm{CO}_{2}$ treatments) limits the comparison between the two studies. Another similar experimental study conducted in the northwest subarctic Pacific revealed a small decrease in haptophyte relative biomass at high $\mathrm{CO}_{2}$ levels $(1000 \mu \mathrm{atm})$ compared to low $\mathrm{CO}_{2}$ level $(180 \mu \mathrm{atm})$ after 6 days and an increase in diatoms biomass in all treatments but no $p \mathrm{CO}_{2}$-related statistical change in the abundance of diatoms and total chl $a$ after 5 days (Endo et al., 2013). Another experiment conducted with water from the diatom-dominated Fe-limited Bering Sea has shown a negative effect of elevated $\mathrm{CO}_{2}$ on diatoms (Sugie et al., 2013; Endo et al., 2015), which was not observed in the $\mathrm{Fe}$-enriched treatments. Thus, despite the differences mentioned above, results from these three experiments suggest that the $\mathrm{pH}$ expected toward the end of this century will only have a small negative impact, if any, on total autotrophic biomass in the HNLC waters of the subarctic North Pacific.

Acidification resulted in the upregulation of $\mathrm{C}$ assimilation in the control (Fig. 4a, b). Such pH-induced increases in C assimilation have previously been reported in $\mathrm{pH}$ manipulation experiments (Riebesell et al., 2007; Tortell et al., 2008). During their study in the same oceanic region, Hopkinson et al. (2010) reported an increase in photosynthetic efficiency in their low-pH treatment, an increase they attributed to energy savings from downregulation of the CCMs. Increasing
$\mathrm{CO}_{2}$ concentrations (lowering $\mathrm{pH}$ ) could have resulted in a downregulation of this costly mechanism, freeing energy for other metabolic pathways such as $\mathrm{C}$ assimilation.

Unexpectedly, the low-pH-induced upregulation of $\mathrm{C}$ assimilation measured at day 4 did not directly translate into an increase in POC in the non-Fe-enriched waters. In point of fact, acidifying non-Fe-enriched waters (Control + Acid treatment) had no effect on chl $a$ or POC concentrations but resulted in a 2-fold and 4-fold increase in absolute and chl $a$ normalized $\mathrm{C}$ assimilation rates, respectively, after 4 days (Fig. 4). The absence of a higher POC concentration in the Control + Acid treatment during our study suggests that the newly assimilated $\mathrm{C}$ was not converted into biomass or that a loss mechanism would impede the buildup of POC. Such mechanisms could include increased grazing by micrograzers or DOC exudation and subsequent transparent exopolymer particle (TEP) formation. An increase in $\mathrm{C}$ uptake without biomass accumulation under acidified conditions has previously been observed during a similar 12-day experiment (Riebesell et al., 2007). This unexpected result was attributed to the release of DOC and subsequent formation of TEPs, which are known to accelerate particle aggregation and sinking. Similar significant stimulation of DOC production at elevated $\mathrm{CO}_{2}$ was reported by Engel et al. (2014) in coastal waters, but only a weak and inconsistent $\mathrm{CO}_{2}$-induced decrease in DOC production was observed by Yoshimura et al. (2014). In the absence of sinking as in our experiment, the aggregation of DOC into TEP may only explain the absence of increase in POC if a large proportion of the TEP produced adsorbed on the walls of the incubation bags. Even though our measurements do not allow identifying the fate of the increased assimilated $\mathrm{C}$ in the high- $p \mathrm{CO}_{2}$ treatment, they point toward a perturbation of the $\mathrm{C}$ cycling, either by an increase in DOC exudation or grazing. If confirmed, such $\mathrm{pH}$-induced modification of $\mathrm{C}$ cycling and pools in HNLC waters could have important impacts on microbial dynamics and $\mathrm{C}$ export.

Overall, our results show that OA in the HNLC waters of the northeast subarctic Pacific may initially negatively impact the growth of haptophytes but stimulate phytoplankton $\mathrm{C}$ assimilation by the Fe-limited cells. In spite of these effects at the cellular and taxonomic levels, lowering the $\mathrm{pH}$ had little effect on the net accumulation of biomass (chl $a$ and POC) after 4 days.

\subsection{Dust fertilization in a high- $\mathrm{CO}_{2}$ northeast subarctic Pacific}

During the 4 days of the experiment, dust fertilization had the same stimulating effect on net $\operatorname{chl} a$ production as the addition of $\mathrm{FeSO}_{4}$. This similarity confirms that the phytoplankton assemblage was Fe-limited when the study was conducted and that $\mathrm{Fe}$ was responsible for the stimulating effect of dust on phytoplankton growth (Fig. 2). However, the average final POC concentration in the Dust treatment 
was $69 \%$ higher than in the $\mathrm{FeSO}_{4}$ treatment, suggesting a more efficient $\mathrm{Fe}$ stimulation of phytoplankton $\mathrm{C}$ assimilation in the former. These results suggest that $2 \mathrm{mg} \mathrm{L}^{-1}$ of CJ2 dust releases at least as much bioavailable $\mathrm{Fe}$ during the first 4 days of the experiment as the addition of $0.6 \mathrm{nmol} \mathrm{L}^{-1}$ $\mathrm{FeSO}_{4}$. We can only speculate as to why $\mathrm{Fe}$ contained in dust stimulated more growth than $\mathrm{FeSO}_{4}$. Part of the answer may be related to the speed at which the Fe is released from dust, a relatively low release rate allowing a more efficient utilization of Fe. In comparison, and as can be seen in Fig. 1, $\mathrm{FeSO}_{4}$ is rapidly utilized and probably scavenged by particles and ligands following fertilization. Diatoms, cyanobacteria, and, to a lesser extent, pelagophytes benefited the most from the dust enrichment, reaching higher group-specific chl $a$ concentrations than the Control incubation at T4. Except dinoflagellates, which did not thrive in the Control, all other groups maintained their biomass in the Dust treatment. This response to $\mathrm{Fe}$ addition is comparable to the one reported for previous small- and large-scale Fe fertilization experiments conducted in the Gulf of Alaska showing an initial increase in the abundance of major taxa and a dominance of diatoms (Boyd et al., 1996; Levasseur et al., 2006; Marchetti et al., 2006; Martin and Fitzwater, 1988; Mélançon et al., 2014). Suzuki et al. (2002a) also observed a remarkable increase in diatoms (fucoxanthin) at station OSP after $\mathrm{Fe}$ addition. We saw no clear difference in the structure of the phytoplankton assemblage regardless of whether dust or $\mathrm{FeSO}_{4}$ was used as fertilizer. In that regard, $\mathrm{FeSO}_{4}$ seems to be a good substitute for dust in studies of the early response ( $<4$ days) of plankton communities to dust deposition in the northeast subarctic Pacific.

DFe measurements were poor indicators of Fe bioavailability following dust deposition in our study. In contrast with the $\mathrm{FeSO}_{4}$ treatment where almost all the added $\mathrm{Fe}$ was still present and measured in the dissolvable pool at T0 (ca. 20 min following the addition), DFe concentrations remained low and near in situ levels during the entire length of the dust-addition experiments (Fig. 1b, c). Considering that the addition of Dust did stimulate algal growth, the low and constant concentration of DFe in the Dust treatment suggests that the release of bioavailable Fe from dust was matched by bacterial and phytoplankton $\mathrm{Fe}$ acquisition. Re-adsorption of the released Fe by the dust particles may also be responsible for the low levels of DFe measured during the experiment (Ye et al., 2011). These results also show that DFe may not be a good indicator of dust deposition events in the oceanic environment where the release of DFe from the low concentrations of dust deposited is unlikely to exceed bio-uptake and re-adsorption on particles. Similar conclusions were reached in a previous study (Mélançon et al., 2014), where total dissolvable Fe (TDFe) was also measured and shown to be a better indicator of Fe bioavailability than DFe.

Our results suggest that after a period of active growth, phytoplankton in the Dust treatment became Fe-limited 4 days into the experiment. This conclusion is supported by the very low absolute and chl $a$ normalized C-fixation rates in the Dust treatment as compared to the Control and $\mathrm{FeSO}_{4}$ treatments at T4 (Fig. 4a), as well as by the FeDFB uptake rates normalized to $\mathrm{C}$ uptake rates, which were higher in the Dust treatment than in the Control (Fig. 4b). Dust particles are known to efficiently adsorb Fe (Ye et al., 2011). The rapid return to Fe deficiency in the Dust treatment may thus result from a combination of increased Fe demand and re-adsorption of $\mathrm{Fe}$ onto dust particles. This explanation implies however that the re-adsorbed Fe becomes less prone to desorption, which needs to be demonstrated. These results suggest that the influence of the Fe released from dust lasted less than 4 days during our experiments. In natural environments, this period of influence may be even shorter due to fast sinking of larger dust particles. Based on Stoke's Law and assuming our dust particles were spherical, CJ-2 dust particles may sink at an average speed of $32 \mathrm{mday}^{-1}$, which would take particles out of a $60 \mathrm{~m}$ deep euphotic zone in $\sim 2$ days. Due to the combined effect of both $\mathrm{Fe}$ re-adsorption on particles and fast sinking, the impact of natural dust deposition may thus be of relatively short duration in the environment, similar to the time frame of our in vitro study.

Decreasing the $\mathrm{pH}$ resulted in a slightly lower biomass (chl $a$ reduced by $16 \%$ and POC by $15 \%$ ) in the Dust + Acid treatment than in the Dust treatment (Fig. 2c). The decrease in biomass corresponded to decreasing trends in the contribution of haptophytes and, to a lesser extent, of pelagophytes and cyanobacteria to total chl $a$ concentrations. As discussed above, a likely explanation for the lower biomass reached after 4 days is the negative effect of acidification on the growth of the coccolithophores (Engel et al., 2005; Harvey et al., 2013; Kroeker et al., 2010). C assimilation rates (absolute and chl $a$-normalized) were ca. 2-fold higher in the Dust + Acid treatment than in the Dust treatment at T4, probably reflecting the stimulating effect of higher $\mathrm{CO}_{2}$ concentrations on diatom $\mathrm{C}$ assimilation. These results reinforce the aforementioned hypothesis that the upregulation of $\mathrm{C}$ assimilation was paired with an increased particulate-C loss via enhanced $\mathrm{C}$ exudation from the cells or increased grazing.

It is obvious from Fig. 2 that the natural variability among the bags of a same treatment as well as the short length of the incubations limited our capacity to statistically distinguish trends resulting from the two treatments (i.e., $\mathrm{Fe}$ or dust addition and acidification). The two-factor ANOVA allowed us to increase the statistical power and detect a negative effect of acidification on chl $a$ concentration after 4 days. This suggests that OA will not increase Fe bioavailability to natural HNLC phytoplankton communities. However, it does not preclude the possibility that acidification may have exacerbated $\mathrm{Fe}$ limitation in our experiment. If the effect of acidification on the growth of calcifying haptophytes was expected, it is not expected in the case of diatoms, pelagophytes, and cyanobacteria. Since these non-calcifying organisms also presented a lower biomass in acidified treatments, 
it is likely that Fe bioavailability has been reduced via interactions between $\mathrm{pH}$, ligands, and $\mathrm{Fe}$ speciation.

\subsection{Impact of acidification and dust deposition on DMSP $_{t}$ and DMS}

The general decrease in $\mathrm{DMSP}_{\mathrm{t}}$ and DMS concentrations measured in all treatments likely reflects the loss of DMSPrich dinoflagellates due to sampling and/or the bottle effect and their replacement by diatoms with low DMSP quotas. In spite of the increase in chl $a$ and POC measured in the $\mathrm{FeSO}_{4}$ and Dust treatments compared to the Control, the alleviation of Fe limitation had no impact on the concentrations of DMSP $\mathrm{t}_{\mathrm{t}}$ or DMS. This can be explained by the lack of significant difference in the abundance of DMSP-rich haptophytes in the Control, $\mathrm{FeSO}_{4}$, and Dust treatments at T4. Indeed, the addition of $\mathrm{FeSO}_{4}$ or dust mostly stimulated the growth of DMSP-poor diatoms, which would have little effect on $\mathrm{DMSP}_{\mathrm{t}}$ concentrations.

Our results show no statistical differences between $\mathrm{DMSP}_{\mathrm{t}}$ concentrations between the acidified and nonacidified treatments after 4 days. Although the short duration of our incubations may explain this lack of response, other studies conducted over longer period of time have reported similar results. For example, lowering the $\mathrm{pH}$ had no effect on $\mathrm{DMSP}_{\mathrm{t}}$ concentrations during the nutrient-stimulated bloom of a community from a Norway fjord (Vogt et al., 2008). In 24-day experiment of Vogt et al. (2008), the absence of effect was attributed to the resistance of the planktonic community considering that similar increases in chl $a$ concentration and species succession were observed in all $\mathrm{CO}_{2}$ treatments. Studies reporting $\mathrm{pH}$-induced changes in $\mathrm{DMSP}_{t}$ concentrations are usually associated with alterations of the structure of the phytoplankton assemblage after several days. For example, a low $\mathrm{pH}$-induced increase in dinoflagellates after 13 days resulted in higher $\mathrm{DMSP}_{\mathrm{t}}$ concentrations during a mesocosm study with Arctic water (Archer et al., 2013).

Lowering the $\mathrm{pH}$ had no measurable effect on DMS concentrations, a result probably also related to the short duration of the experiment. Previous studies showed either an increase or decrease in DMS concentrations with acidification, but these differences become measurable late in the experiment at or after the peak of the blooms. For example, during the experiment PeECE III in Raunefjorden, Norway, Wingenter et al. (2007) observed an increase in the timeintegrated average amount of DMS at high $\mathrm{CO}_{2}$, but the $\mathrm{pH}$ related differences could only be observed after 6 days. In this case, the authors attributed the $\mathrm{pH}$ effect to a difference in viral attack and phytoplankton lysis at the chl $a$ peak, a situation that is not likely to have occurred in our short incubations. Contrastingly, a decrease in DMS concentrations with high $\mathrm{CO}_{2}$ was observed during other mesocosm studies conducted in the same fjord (Hopkins et al., 2010; Avgoustidi et al., 2012). These authors suggested that the dominance of flagellates and picoeucaryotes during their study as com- pared to coccolithophores during PeECE III could explain the divergent responses observed with regard to DMS production.

Archer et al. (2013) also measured a decrease in DMS concentration under high- $\mathrm{CO}_{2}$ conditions in Arctic waters, a decrease they attributed to an increase in bacterial production and decrease in DMS yield. It should be noted that none of the experiments described above reports an effect of $\mathrm{CO}_{2}$ on DMS in the first 4 days. The sole study so far showing a rapid effect of a decreased pH is by Hopkins and Archer (2014), who measured a decrease in DMSP and an increase in DMS after 4 days during shipboard bioassays experiments with NW European waters. In that case, the changes in DMSP and DMS were associated with a rapid decline in the abundance of small cells in the acidified treatments and a possible cellular release and cleavage of DMSP to DMS. Nonetheless, their results show a regional variability of the responses. The lack of response of DMS concentration to $p \mathrm{CO}_{2}$ in our incubations might reflect this natural variability and a particular resistance of our initial community to acidification.

\section{Conclusions}

This study demonstrates that the degree of OA expected to occur by the end of the century is likely to have a detectable but minor impact on the short-term response of Fe-limited planktonic communities to sporadic atmospheric Fe-dust depositions. The addition of $\mathrm{FeSO}_{4}$ and Asian dust stimulated the growth of all major phytoplankton groups during our $96 \mathrm{~h}$ incubations, thereby confirming the Fe-depleted status of the community and the potential of natural dust deposition for stimulating phytoplankton growth in this HNLC region. In the acidified treatments, $\mathrm{Fe}$ in the form of $\mathrm{FeSO}_{4}$ or Asian dust still had a fertilizing effect on the algal assemblage but to a lesser extent than in the nonacidified treatment. The trends reported here suggest that OA could moderate the growth response of pelagophytes and haptophytes to dust deposition. The fact that non-calcifying taxa were also affected by acidification suggests that the lower $\mathrm{pH}$ possibly interferes with ligands, Fe speciation, and transporters to reduce Fe bioavailability in these HNLC waters. Finally, our results suggest a low sensitivity of the DMS dynamics to acidification, both under Fe-limited and Fe-replete conditions, in the northeast subarctic Pacific. In order to understand the mechanisms behind this apparent resistance, studies on DMSP and DMS phytoplankton and bacterioplankton metabolisms during longer incubation periods are advisable.

Acknowledgements. We wish to thank the following people: the officers, crew, and fellow scientists aboard the CCGS John P. Tully for assistance during the cruise; fellow scientists at the Institute of Ocean Sciences (Sidney, Canada) and the University of Victoria (Victoria, Canada) for providing help, advice and access to labs; Shigenobu Takeda for providing CJ2 dust; and Denis Talbot for 
help with statistical analyses. This project was funded by the Natural Sciences and Engineering Research Council (NSERC). J. Mélançon received scholarships from the Fonds de Recherche du Québec - Nature et Technologies (FQRNT), Québec-Océan, and the biology department of Université Laval. The Line-P program is sponsored by Fisheries and Oceans Canada. This research was also supported by the Major International Joint Research Project of the National Natural Science Foundation of China (Grant no. 41320104008$)$.

Edited by: K. Suzuki

\section{References}

Archer, S. D., Kimmance, S. A., Stephens, J. A., Hopkins, F. E., Bellerby, R. G. J., Schulz, K. G., Piontek, J., and Engel, A.: Contrasting responses of DMS and DMSP to ocean acidification in Arctic waters, Biogeosciences, 10, 1893-1908, doi:10.5194/bg10-1893-2013, 2013.

Arnold, H. E., Kerrison, P., and Steinke, M.: Interacting effects of ocean acidification and warming on growth and DMS-production in the haptophyte coccolithophore Emiliania huxleyi, Glob. Change Biol., 19, 1007-1016, 2013.

Avgoustidi, V., Nightingale, P. D., Joint, I., Steinke, M., Turner, S. M., Hopkins, F. E., and Liss, P. S.: Decreased marine dimethyl sulfide production under elevated $\mathrm{CO}_{2}$ levels in mesocosm and in vitro studies, Environ. Chem., 9, 399-404, 2012.

Barwell-Clarke, J. and Whitney, F.: Institute of Ocean Sciences nutrient methods and analysis., Canadian Technical Report. Hydrography Ocean Sciences, 1996, 182, vi + 43 pp., 1996.

Bishop, J. K. B., Davis, R. E., and Sherman, J. T.: Robotic observations of dust storm enhancement of carbon biomass in the North Pacific, Science, 298, 817-821, 2002.

Boyd, P. W., Muggli, D. L., Varela, D. E., Goldblatt, R. H., Chretien, R., Orians, K. J., and Harrison, P. J.: In vitro iron enrichment experiments in the NE subarctic Pacific, Mar. Ecol.-Prog. Ser., 136, 179-193, 1996.

Boyd, P. W., Wong, C. S., Merrill, J., Whitney, F., Snow, J., Harrison, P. J., and Gower, J.: Atmospheric iron supply and enhanced vertical carbon flux in the NE subarctic Pacific: Is there a connection?, Global Biogeochem. Cy., 12, 429-441, 1998.

Boyd, P. W., Strzepek, R., Takeda, S., Jackson, G., Wong, C. S., McKay, R. M., Law, C., Kiyosawa, H., Saito, H., Sherry, N., Johnson, K., Gower, J., and Ramaiah, N.: The evolution and termination of an iron-induced mesoscale bloom in the northeast subarctic Pacific, Limnol. Oceanogr., 50, 1872-1886, 2005.

Boyd, P. W., Jickells, T., Law, C. S., Blain, S., Boyle, E. A., Buesseler, K. O., Coale, K. H., Cullen, J. J., de Baar, H. J. W., Follows, M., Harvey, M., Lancelot, C., Levasseur, M., Owens, N. P. J., Pollard, R., Rivkin, R. B., Sarmiento, J., Schoemann, V., Smetacek, V., Takeda, S., Tsuda, A., Turner, S., and Watson, A. J.: Mesoscale iron enrichment experiments 1993-2005: Synthesis and future directions, Science, 315, 612-617, 2007.

Breitbarth, E., Bellerby, R. J., Neill, C. C., Ardelan, M. V., Meyerhöfer, M., Zöllner, E., Croot, P.L., and Riebesell, U.: Ocean acidification affects iron speciation during a coastal seawater mesocosm experiment, Biogeosciences, 7, 1065-1073, doi:10.5194/bg-7-1065-2010, 2010.
Crawford, W. R., Brickley, P. J., and Thomas, A. C.: Mesoscale eddies dominate surface phytoplankton in northern Gulf of Alaska, Prog. Oceanogr., 75, 287-303, 2007.

Cullen, J. T., Chong, M., and Ianson, D.: British Columbian continental shelf as a source of dissolved iron to the subarctic northeast Pacific Ocean, Global Biogeochem. Cy., 23, GB4012, doi:10.1029/2008GB003326, 2009.

Cutter, G., Andersson, P., Codispoti, L., Croot, P., François, R., Lohan, M. C., Obata, H., and Rutgers v. d. Loeff, M.: Sampling and sample-handling protocols for GEOTRACES cruises, 2010 GEOTRACES Standards and intercalibration committee (Eds.), 144 pp., 2010.

de Baar, H. J. W., Boyd, P. W., Coale, K. H., Landry, M. R., Tsuda, A., Assmy, P., Bakker, D. C. E., Bozec, Y., Barber, R. T., Brzezinski, M. A., Buesseler, K. O., Boye, M., Croot, P.L., Gervais, F., Gorbunov, M. Y., Harrison, P. J., Hiscock, W. T., Laan, P., Lancelot, C., Law, C. S., Levasseur, M., Marchetti, A., Millero, F. J., Nishioka, J., Nojiri, Y., van Oijen, T., Riebesell, U., Rijkenberg, M. J. A., Saito, H., Takeda, S., Timmermans, K. R., Veldhuis, M. J. W., Waite, A. M., and Wong, C. S.: Synthesis of iron fertilization experiments: From the iron age in the age of enlightenment, J. Geophys. Res.-Oceans, 110, C09S16, doi:10.1029/2004JC002601, 2005.

Dickson, A. G.: Standard potential of the reaction: $\mathrm{AgCl}(\mathrm{s})+\mathrm{H}_{2}(\mathrm{~g})=\mathrm{Ag}(\mathrm{s})+\mathrm{HCl}(\mathrm{aq})$, and the standard acidity constant of the ion $\mathrm{HSO}_{4}^{-}$in synthetic sea water from 273.15 to $318.15 \mathrm{~K}$, J. Chem. Thermodyn., 22, 113-127, 1990.

Dickson, A. G. and Millero, F. J.: A comparison of the equilibrium constants for the dissociation of carbonic acid in seawater media, Deep-Sea Res., 34, 1733-1743, 1987.

Dickson, A. G., Sabine, C. L., and Christian, J. R. (Eds): Guide to best practices for ocean $\mathrm{CO}_{2}$ measurements, PICES Special Publication, 3, 191 pp., 2007.

Duce, R. A. and Tindale, N. W.: Atmospheric Transport of Iron and Its Deposition in the Ocean, Limnol. Oceanogr., 36, 1715-1726, 1991.

Endo, H., Yoshimura, T., Kataoka, T., and Suzuki, K.: Effects of $\mathrm{CO}_{2}$ and iron availability on phytoplankton and eubacterial community compositions in the northwest subarctic Pacific, J. Exp. Mar. Biol. Ecol., 439, 160-175, 2013.

Endo, H., Sugie, K., Yoshimura, T., and Suzuki, K.: Effects of $\mathrm{CO}_{2}$ and iron availability on rbcL gene expression in Bering Sea diatoms, Biogeosciences, 12, 2247-2259, doi:10.5194/bg12-2247-2015, 2015.

Engel, A., Zondervan, I., Aerts, K., Beaufort, L., Benthien, A., Chou, L., Delille, B., Gattuso, J. P., Harlay, J., Heemann, C., Hoffmann, L., Jacquet, S., Nejstgaard, J., Pizay, M. D., RochelleNewall, E., Schneider, U., Terbrueggen, A., and Riebesell, U.: Testing the direct effect of $\mathrm{CO}_{2}$ concentration on a bloom of the coccolithophorid Emiliania huxleyi in mesocosm experiments, Limnol. Oceanogr., 50, 493-507, 2005.

Engel, A., Piontek, J., Grossart, H.-P., Riebesell, U., Schulz, K. G., and Sperling, M.: Impact of $\mathrm{CO}_{2}$ enrichment on organic matter dynamics during nutrient induced coastal phytoplankton blooms, J. Plankton Res., 36, 641-657, 2014.

Gattuso, J.-P., Mach, K. J., and Morgan, G.: Ocean acidification and its impacts: an expert survey, Clim. Change, 117, 725-738, 2013.

Hamme, R. C., Webley, P. W., Crawford, W. R., Whitney, F. A., DeGrandpre, M. D., Emerson, S. R., Eriksen, C. C., Gies- 
brecht, K. E., Gower, J. F. R., Kavanaugh, M. T., Pena, M. A., Sabine, C. L., Batten, S. D., Coogan, L. A., Grundle, D. S., and Lockwood, D.: Volcanic ash fuels anomalous plankton bloom in subarctic northeast Pacific, Geophys. Res. Lett., 37, L19604, doi:10.1029/2010GL044629, 2010.

Harrison, P., Boyda, P., Varela, D., Takeda, S., Shiomoto, A., and Odate, T.: Comparison of factors controlling phytoplankton productivity in the NE and NW subarctic Pacific gyres, Progr. Oceanogr., 43, 205-234, 1999.

Harvey, B. P., Gwynn-Jones, D., and Moore, P. J.: Meta-analysis reveals complex marine biological responses to the interactive effects of ocean acidification and warming, Ecol. Evolut., 3, 10161030, 2013.

Hopkins, F. E. and Archer, S. D.: Consistent increase in dimethyl sulfide (DMS) in response to high $\mathrm{CO}_{2}$ in five shipboard bioassays from contrasting NW European waters, Biogeosciences, 11, 4925-4940, doi:10.5194/bg-11-4925-2014, 2014.

Hopkins, F. E., Turner, S. M., Nightingale, P. D., Steinke, M., Bakker, D., and Liss, P. S.: Ocean acidification and marine trace gas emissions, P. Natl. Acad. Sci. USA, 107, 760-765, 2010.

Hopkinson, B. M., Xu, Y., Shi, D., McGinn, P. J., and Morel, F. M. M.: The effect of $\mathrm{CO}_{2}$ on the photosynthetic physiology of phytoplankton in the Gulf of Alaska, Limnol. Oceanogr., 55, 20112024, 2010.

Hoppe, C. J. M., Hassler, C. S., Payne, C. D., Tortell, P. D., Rost, B., and Trimborn, S.: Iron limitation modulates ocean acidification effects on southern ocean phytoplankton communities, Plos One, 8, e79890, doi:10.1371/journal.pone.0079890, 2013.

Hudson, R. J. M. and Morel, F. M. M.: Distinguishing between extra- and intracellular iron in marine phytoplankton, Limnol. Oceanogr., 34, 1113-1120, 1989.

Hutchins, D. A., Franck, V. M. Brzezinski, M. A., and Bruland, K. W.: Inducing phytoplankton iron limitation in iron-replete coastal waters with a strong chelating ligand, Limnol. Oceanogr., 44, 1009-1018, 1999.

Hwang, H. and Ro, C.-U.: Single-particle characterization of "Asian Dust" certified reference materials using low-Z particle electron probe X-ray microanalysis, Spectrochim. Ac. B, 61, 400-406, 2006.

Jickells, T. D., An, Z. S., Andersen, K. K., Baker, A. R., Bergametti, G., Brooks, N., Cao, J. J., Boyd, P. W., Duce, R. A., Hunter, K. A., Kawahata, H., Kubilay, N., laRoche, J., Liss, P. S., Mahowald, N., Prospero, J. M., Ridgwell, A. J., Tegen, I., and Torres, R.: Global iron connections between desert dust, ocean biogeochemistry, and climate, Science, 308, 67-71, 2005.

Johnson, K. M., Wills, K. D., Butler, D. B., Johnson, W. K., and Wong, C. S.: Coulometric total carbon dioxide analysis for marine studies: maximizing the performance of an automated gas extraction system and coulometric detector, Mar. Chem., 44, 167-187, 1993.

Johnson, K. S., Elrod, V., Fitzwater, S., Plant, J., Boyle, E., Bergquist, B., Bruland, K., Aguilar-Islas, A., Buck, K., and Lohan, M.: Developing standards for dissolved iron in seawater, Eos. T. Am. Geophys. Un., 88, 131-132, 2007.

Johnson, K. W., Miller, L. A., Sutherland, N. E., and Wong, C. S.: Iron transport by mesoscale Haida eddies in the Gulf of Alaska, Deep-Sea Res. Pt. II, 52, 933-953, 2005.

Keller, M. D., Bellows, W. K., and Guillard, R. R. L.: Dimethyl sulfide production in marine phytoplankton, in: Biogenic sulfur in the environment, ACS Symposium Series, edited by: Saltzman, E. S. and Cooper, W. J., Am. Chem. Soc., 393, 167-182, 1989.

Kim, J.-M., Lee, K., Yang, E. J., Shin, K., Noh, J. H., Park, K.-T., Hyun, B., Jeong, H.-J., Kim, J.-H., Kim, K. Y., Kim, M., Kim, H.C., Jang, P.-G., and Jang, M.-C.: Enhanced production of oceanic dimethylsulfide resulting from $\mathrm{CO}_{2}$-induced grazing activity in a high- $\mathrm{CO}_{2}$ world, Environ. Sci. Technol., 44, 8140-8143, 2010.

Kroeker, K. J., Kordas, R. L., Crim, R. N., and Singh, G. G.: Metaanalysis reveals negative yet variable effects of ocean acidification on marine organisms, Ecol. Lett., 13, 1419-1434, 2010.

Kroeker, K. J., Kordas, R. L., Crim, R., Hendriks, I. E., Ramajo, L., Singh, G. S., Duarte, C. M., and Gattuso, J.-P.: Impacts of ocean acidification on marine organisms: quantifying sensitivities and interaction with warming, Glob. Change Biol., 19, 1884-1896, 2013.

Lam, P. J. and Bishop, J. K. B.: The continental margin is a key source of iron to the HNLC North Pacific Ocean, Geophys. Res. Lett., 35, L07608, doi:10.1029/2008GL033294, 2008.

Lee, P. A., Rudisill, J. R., Neeley, A. R., Maucher, J. M., Hutchins, D. A., Feng, Y., Hare, C. E., Leblanc, K., Rose, J. M., Wilhelm, S. W., Rowe, J. M., and DiTullio, G. R.: Effects of increased $p \mathrm{CO}_{2}$ and temperature on the North Atlantic spring bloom. III. Dimethylsulfoniopropionate, Mar. Ecol. Prog. Ser, 388, 41-49, 2009.

Levasseur, M., Scarratt, M. G., Michaud, S., Merzouk, A., Wong, C. S., Arychuk, M., Richardson, W., Rivkin, R. B., Hale, M., Wong, E., Marchetti, A., and Kiyosawa, H.: DMSP and DMS dynamics during a mesoscale iron fertilization experiment in the Northeast Pacific - Part I: Temporal and vertical distributions, Deep-Sea Res. Pt. II, 53, 2353-2369, 2006.

Mackey, M. D., Mackey, D. J., Higgins, H. W., and Wright, S. W.: CHEMTAX - A program for estimating class abundances from chemical markers: Application to HPLC measurements of phytoplankton, Mar. Ecol. Prog. Ser., 144, 265-283, 1996.

Maldonado, M. T. and Price, N. M.: Utilization of iron bound to strong organic ligands by plankton communities in the subarctic Pacific Ocean, Deep-Sea Res. Pt. II, 46, 2447-2473, 1999.

Maldonado, M. T., Allen, A. E., Chong, J. S., Lin, K., Leus, D., Karpenko, N., and Harris, S. L.: Copper-dependent iron transport in coastal and oceanic diatoms, Limnol. Oceanogr., 51, doi:10.4319/lo.2006.51.4.1729, 2006.

Marchetti, A., Sherry, N. D., Kiyosawa, H., Tsuda, A., and Harrison, P. J.: Phytoplankton processes during a mesoscale iron enrichment in the NE subarctic Pacific: Part I - Biomass and assemblage, Deep-Sea Res. Pt. II, 53, 2095-2113, 2006.

Martin, J. H. and Fitzwater, S. E.: Iron-deficiency limits phytoplankton growth in the northeast Pacific subarctic, Nature, 331, 341343, 1988.

Meehl, G. A., Stocker, T. F., Collins, W. D., Friedlingstein, P., Gaye, A. T., Gregory, J. M., Kitoh, A., Knutti, R., Murphy, J. M., Noda, A., Raper, S. C. B., Watterson, I. G., Weaver, A. J., and Zhao, Z.C.: Global Climate Projections, in: Climate Change 2007: The Physical Science Basis. Contribution of Working Groups 1 to the Fourth Assessment Report of the Intergovernmental Panel on Climate Change, edited by: Solomon, S., Qin, D., Manning, M., Chen, Z., Marquis, M., Averyt, K. B., Tignor, M., and Miller, H. L., Cambridge University Ptress, Cambridge, United Kingdom and New York, NY, USA, 2007. 
Mehrbach, C., Culberson, C. H., Hawley, J. E., and Pytkowicx, R. M.: Measurement of the apparent dissociation constants of carbonic acid in seawater at atmospheric pressure, Limnol. Oceanogr., 18, 897-907, 1973.

Mélançon, J., Levasseur, M., Lizotte, M., Delmelle, P., Cullen, J., Hamme, R. C., Pena, A., Simpson, K. G., Scarratt, M., and Tremblay, J.-E.: Early response of the northeast subarctic Pacific plankton assemblage to volcanic ash fertilization, Limnol. Oceanogr., 59, 55-67, 2014.

Nishikawa, M., Hao, Q., and Morita, M.: Preparation and evaluation of certified reference materials for Asian mineral dust, Global Environ. Res., 4, 103-113, 2000.

Obata, H., Karatani, H., and Nakayama, E.: Automated determination of iron in seawater by chelating resin concentration and chemiluminescence detection, Anal. Chem., 65, 1524-1528, 1993.

Obata, H., Karatani, H., Matsui, M., and Nakayama, E.: Fundamental studies for chemical speciation of iron in seawater with an improved analytical method, Mar. Chem., 56, 97-106, 1997.

Olgun, N., Duggen, S., Croot, P. L., Delmelle, P., Dietze, H., Schacht, U., Oskarsson, N., Siebe, C., Auer, A., and GarbeSchoenberg, D.: Surface ocean iron fertilization: The role of airborne volcanic ash from subduction zone and hot spot volcanoes and related iron fluxes into the Pacific Ocean, Global Biogeochem. Cy., 25, GB4001, doi:10.1029/2009GB003761, 2011.

Ooki, A., Nishioka, J., Ono, T., and Noriki, S: Size dependence of iron solubility of Asian mineral dust particles, J. Geophys. Res.Atmos., 114, D3202, doi:10.1029/2008JD010804, 2009.

Pierrot, D. E., Lewis, E., and Wallace, D. W. R.: MS Excel program developed for $\mathrm{CO}_{2}$ system calcultations, Carbon Dioxide Information Analysis Center, Oak Ridge National Laboratory, US Departement of Energy, Oak Ridge, Tennessee, 2006.

Reinfelder, J. R.: Carbon concentrating mechanisms in eukaryotic marine phytoplankton, Ann. Rev. Mar. Sci., 3, 291-315, 2011.

Riebesell, U., Schulz, K. G., Bellerby, R., Botros, M., Fritsche, P., Meyerhöfer, M., Neill, C., Nondal, G., Oschlies, A., and Wohlers, J.: Enhanced biological carbon consumption in a high $\mathrm{CO}_{2}$ ocean, Nature, 450, 545-548, 2007.

Riebesell, U., Fabry, V. J., Hansson, L., and Gattuso, J. P.: Guide to best practices for ocean acidification research and data reporting, Publications Office of the European Union, Luxembourg, 2010.

Royer, S. J., Levasseur, M., Lizotte, M., Arychuk, M., Scarratt, M. G., Wong, C. S., Lovejoy, C., Robert, M., Johnson, K., Pena, A., Michaud, S., and Kiene, R. P.: Microbial dimethylsulfoniopropionate (DMSP) dynamics along a natural iron gradient in the northeast subarctic Pacific, Limnol. Oceanogr., 55, 1614-1626, 2010.

Sasaki, H., Saitoh, S.-i., and Kishino, M.: Bio-optical properties of seawater in the western subarctic gyre and alaskan gyre in the subarctic North Pacific and the southern Bering Sea during the summer of 1997, J. Oceanogr., 57, 275-284, 2001.

Scarratt, M., Cantin, G., Levasseur, M., and Michaud, S.: Particle size-fractionated kinetics of DMS production: where does DMSP cleavage occur at the microscale?, J. Sea Res., 43, 245252,2000

Semeniuk, D. M., Cullen, J. T., Johnson, W. K., Gagnon, K., Ruth, T. J., and Maldonado, M. T.: Plankton copper requirements and uptake in the subarctic Northeast Pacific Ocean, Deep-Sea Res. Pt. I, 56, 1130-1142, 2009.
Semeniuk, D. M., Taylor, R. L., Bundy, R. M., Johnson, W. K., Cullen, J. T., Robert, M., Barbeau, K. A., and M. T. Maldonado.: Iron-copper interactions in iron-limited phytoplankton in the northeast subarctic Pacific Ocean, Limnol. Oceanogr., 61, 279-297, doi:10.1002/lno.10210, 2016.

Shi, D., Xu, Y., Hopkinson, B. M., and Morel, F. M. M.: Effect of ocean acidification on iron availability to marine phytoplankton, Science, 327, 676-679, 2010.

Strickland, J. D. H. and Parsons, T. R.: A practical handbook of seawater analysis (2nd Edn.), Journal of Fisheries Research, Board of Canada, 167, 311 pp., 1972.

Sugie, K., Endo, H., Suzuki, K., Nishioka, J., Kiyosawa, H., and Yoshimura, T.: Synergistic effects of $p \mathrm{CO}_{2}$ and iron availability on nutrient consumption ratio of the Bering Sea phytoplankton community, Biogeosciences, 10, 6309-6321, doi:10.5194/bg-106309-2013, 2013.

Suzuki, K., Liu, H., Saino, T., Obata, H., Takano, M., Okamura, K., Sohrin, Y., and Fujishima, Y.: East-west gradients in the photosynthetic potential of phytoplankton and iron concentration in the subarctic Pacific Ocean during early summer, Limnol. Oceanogr., 47, 1581-1594, 2002a.

Suzuki, K., Minami, C., Liu, H., and Saino, T.: Temporal and spatial patterns of chemotaxonomic algal pigments in the subarctic $\mathrm{Pa}-$ cific and the Bering Sea during early summer of 1999, Deep-Sea Res. Pt. II, 49, 5685-5704, 2002b.

Taylor, R. L., Semeniuk, D. M., Payne, C. D., Zhou, J., Tremblay, J.-E., Cullen, J. T., and Maldonado, M. T.: Colimitation by light, nitrate, and iron in the Beaufort Sea in late summer, J. Geophys. Res.-Oceans, 118, 3260-3277, 2013.

Tortell, P. D., Payne, C. D., Li, Y. Y., Trimborn, S., Rost, B., Smith, W. O., Riesselman, C., Dunbar, R. B., Sedwick, P., and DiTullio, G. R.: $\mathrm{CO}_{2}$ sensitivity of Southern Ocean phytoplankton, Geophys. Res. Lett., 35, L04605, doi:10.1029/2007GL032583, 2008.

Vogt, M., Steinke, M., Turner, S., Paulino, A., Meyerhöfer, M., Riebesell, U., LeQuéré, C., and Liss, P.: Dynamics of dimethylsulphoniopropionate and dimethylsulphide under different $\mathrm{CO}_{2}$ concentrations during a mesocosm experiment, Biogeosciences, 5, 407-419, doi:10.5194/bg-5-407-2008, 2008.

Wingenter, O. W., Haase, K. B., Zeigler, M., Blake, D. R., Rowland, F. S., Sive, B. C., Paulino, A., Thyrhaug, R., Larsen, A., and Schulz, K.: Unexpected consequences of increasing $\mathrm{CO}_{2}$ and ocean acidity on marine production of DMS and $\mathrm{CH}_{2} \mathrm{ClI}$ : Potential climate impacts, Geophys. Res. Lett., 34, L05710, doi:10.1029/2006GL028139, 2007.

Wong, C. S., Wong, S. E., Richardson, W. A., Smith, G. E., Arychuk, M. D., and Page, J. S.: Temporal and spatial distribution of dimethylsulfide in the subarctic northeast Pacific Ocean: a high-nutrient - low-chlorophyll region, Tellus B, 57, 317-331, 2005.

Wong, C. S., Johnson, W. K., Sutherland, N., Nishioka, J., Timothy, D. A., Robert, M., and Takeda, S.: Iron speciation and dynamics during SERIES, a mesoscale iron enrichment experiment in the NE Pacific, Deep-Sea Res. Pt. II, 53, 2075-2094, 2006.

Ye, Y., Wagener, T., Völker, C., Guieu, C., and Wolf-Gladrow, D. A.: Dust deposition: iron source or sink? A case study, Biogeosciences, 8, 2107-2124, doi:10.5194/bg-8-2107-2011, 2011.

Yoshimura, T., Sugie, K., Endo, H., Suzuki, K., Nishioka, J., and Ono, T.: Organic matter production response to $\mathrm{CO}_{2}$ increase in open subarctic plankton communities: Comparison of six micro- 
cosm experiments under iron-limited and -enriched bloom conditions, Deep-Sea Res. Pt. I, 94, 1-14, 2014.

Zapata, M., Rodriguez, F., and Garrido, J. L.: Separation of chlorophylls and carotenoids from marine phytoplankton: a new HPLC method using a reversed phase C-8 column and pyridinecontaining mobile phases, Mar. Ecol. Progr. Ser., 195, 29-45, 2000 .
Zapata, M., Jeffrey, S. W., Wright, S. W., Rodríguez, F., Garrido, J. L., and Clementson, L.: Photosynthetic pigments in 37 species (65 strains) of Haptophyta: implications for oceanography and chemotaxonomy, Mar. Ecol. Prog. Ser., 270, 83-102, 2004. 